\title{
المسئولية الجنائية لاطبيب عن الإعلانات الطبية الخادعة وقبول العطايا \\ "دراسة مقارنة"
}

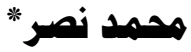

تهدف المقالة إلى معالجة قضية قبول العطايا والإعلانات الطبية الخادعة، ومدى المسئولية

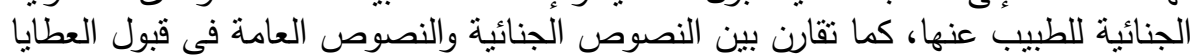

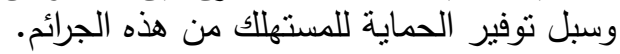

\section{مقدمة مقة}

أسهم التطور العالمى فى مجال الطب وفى مجال التروبج للمنتجات الطبية فى مكافحة العديد من الأمراض الوبائية والمستعصية، كما أسهم الإعلام فى تقريب المسافات تلك، ولكن قد يفضى الإعلان والمقدم فيه توصية من طبيب مشهور إلى المساس بإحدى المصالح أو الحقوق التى يوليها المشرع، وبخاصة فيما يعد تضليلاً أو ضاراً بالصحة العامة(') عن طريق إتباع الجماهير المتابعة لتلك الوسائل للحصول على تللك المنتجات دون مراجعة طبيب الأسرة، وهو ما يقتضى تحديد معالم تلك الحماية من الناحية الجنائية، وبيان قواعد المسئولية عنها، وصور قبول العطايا من قبل الأطباء للتوصية بوصفات طبية معينة للمرضى، والتى قد لا تكون لها ضرورة طبية، ويصعب إثبات ذلك فى ميدان الابتزاز لمرضاه، أو حتى إدراجها تحت نطاق الرشوة دن شركات الأدوية للأطباء، لأن الرشوة ما يعطى بعد طلبه، أو ما يعطى لإبطال حق أو لإحقاق باطل، والهدية ما يدفع إليه ابتداء(؟). * مدرس القانون الجنائى، جامعة طيبة، أكاديمية القاهرة الجديدة. المجلة الجنائية القومية، المجلد الواحد والستون، العدد الثانى، يوليو 11 ـr. 
وفى هذا الصدد يمكننا أن نؤكد أن المشرع قد تأخر ردحاً طويلاً من

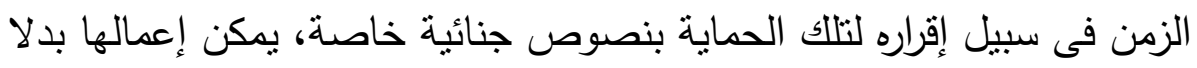

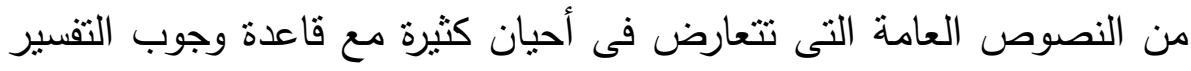

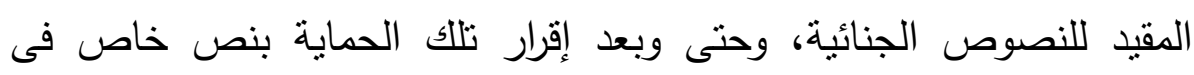

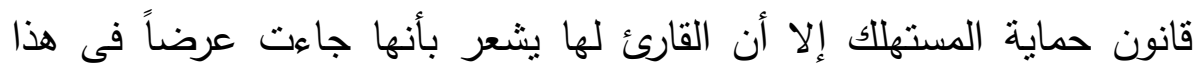

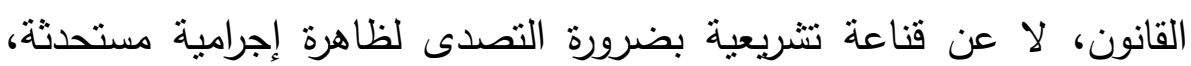
تنال من حقوق تتمتع بحماية جنائية خاصة، تقديرا لأهميتها.

أهمية الدراسة لا شك أن تأثيرات الإعلانات الخادعة والمستخذم فيها الأطباء المتخصصون

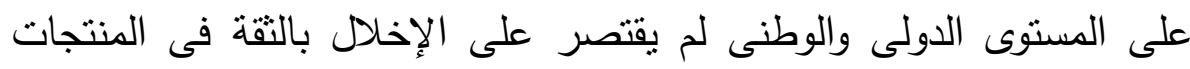

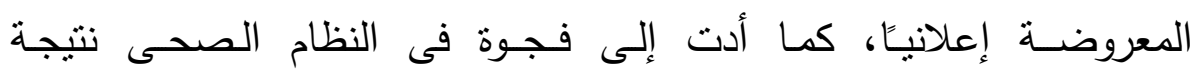

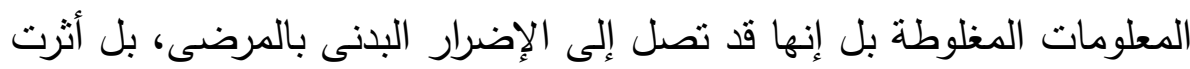

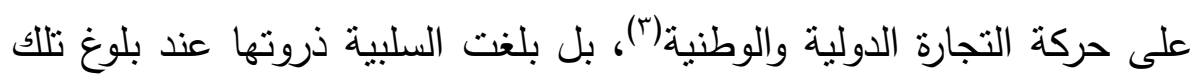

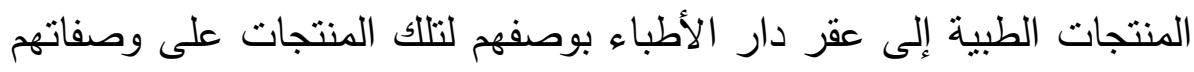

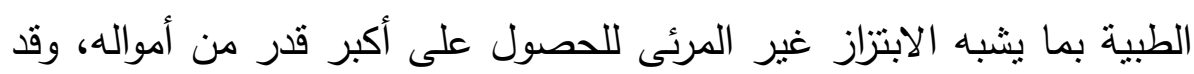

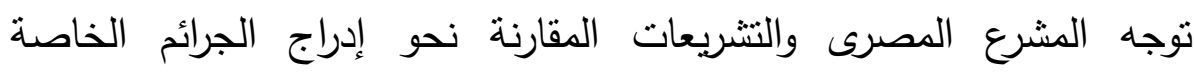
بالإعلانات على أسساس أنها جرائم اقتصادية، واعتبار الدمارسات الديات المهنية

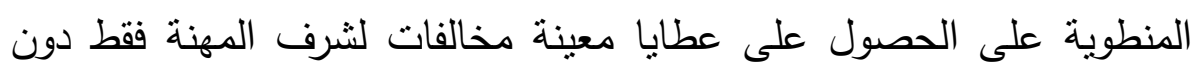
وجود جزاءات فاعلة، وإلى تفضيل الجزاءات الاقتصادية بالنسبة للإعلانات

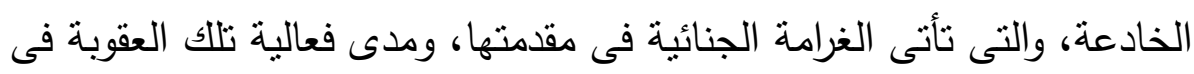

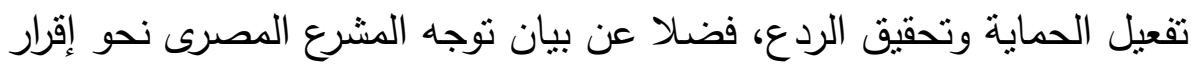

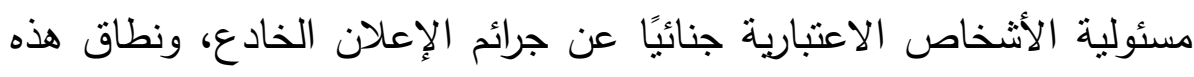


المسئولية وضوابطها والعقوبات التى يمكن أن تطبق فى حالة ثبوتها(؛).

إشكالية الدراسة

لا مندوحة أن الإعلان يمخر عباب الأسواق كما يمخر الاقتصاد بحر التتمية

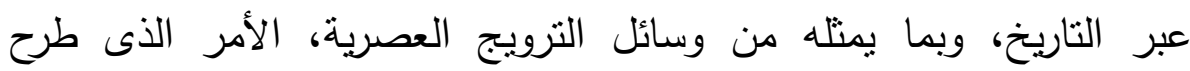

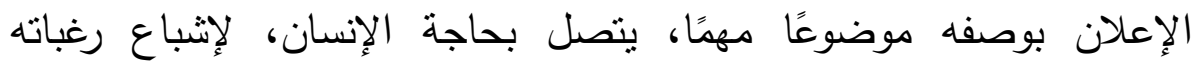

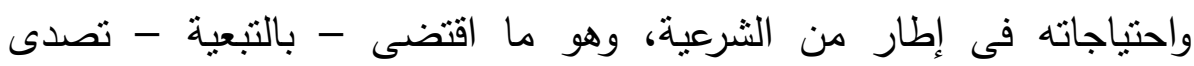

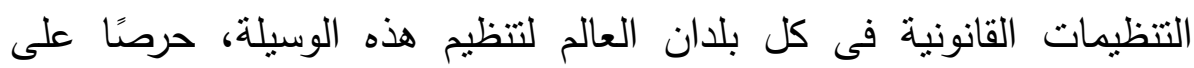

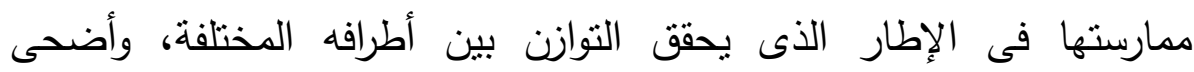
الإعلان الطبى شريحة كبرى فى مجمل الإعلانات الاستهلاكية، فضلا عن الإنان النان

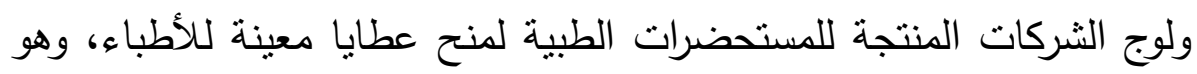
ما أدى إلى وجود خلل فى معايير العلاج، وإمكانية الإضرار بالمبنه المرضى.

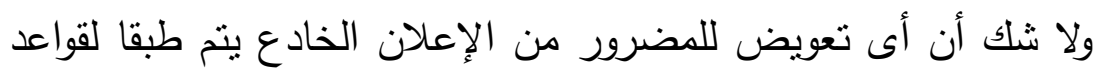

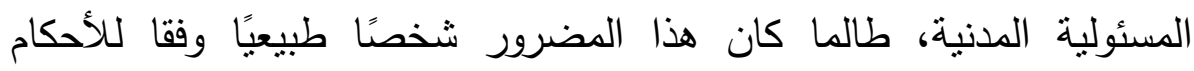
العامة، ولكن ما يثير الجدل هو قبول حق النقابات المهنية وجماعات حماية

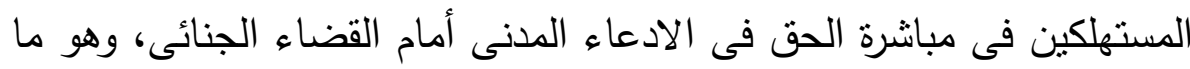

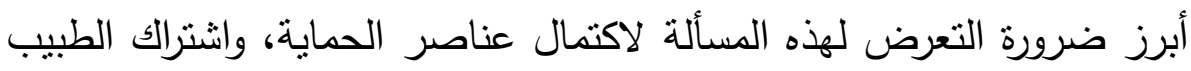

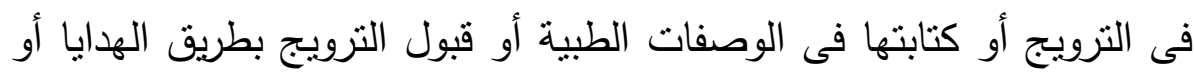
الحصول على نسبة من مبيعات المنتج. 


\section{منهجية الدراسة}

استخدت الدراسة المنهج الاستقرائى والوصفى والتحليلى لتحقيق الهدف من

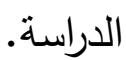

\section{أولا: هاهية الوهم أو الفديعة الإعلانية}

من اللازم أن يهتم المشرع الجنائى بتحديد معايير ثابتة وواضحة للمجتمع اوعايه

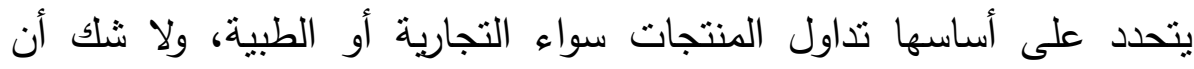

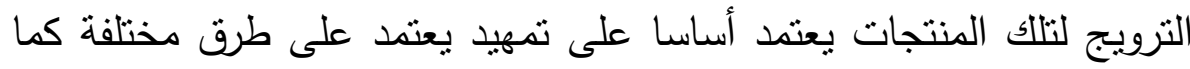

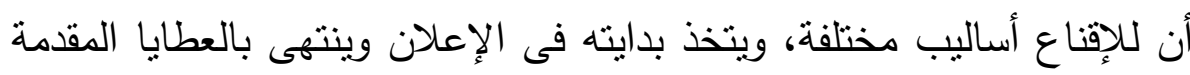

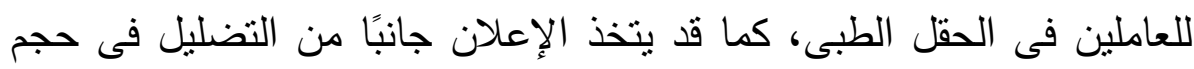
الأثز المترتب على استخدام منتج طبى معين، وجماع من يلجأ للتضليل

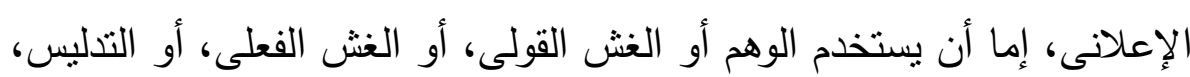

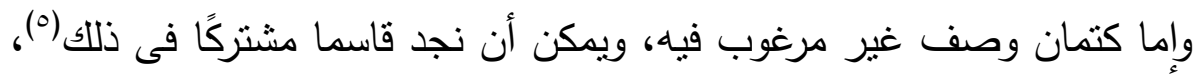

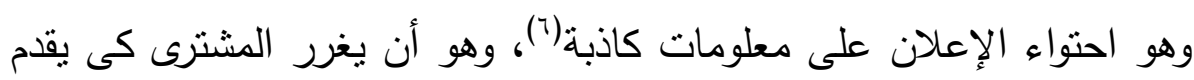

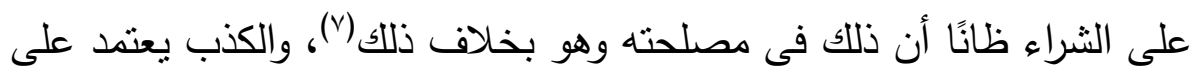
عنصرين هما: مضمون زائف وقصد الغش أو تزييف الحقيقة، والخداع هو

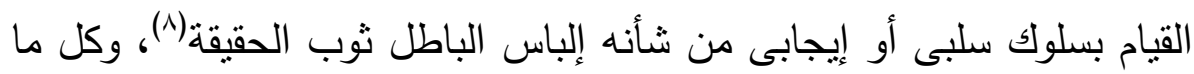
من شأنه خداع المتلقى يعتبر تضليلاًا (9).

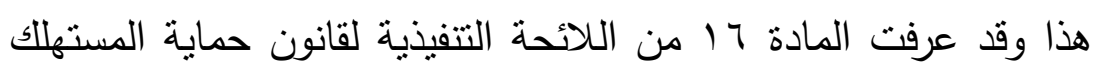

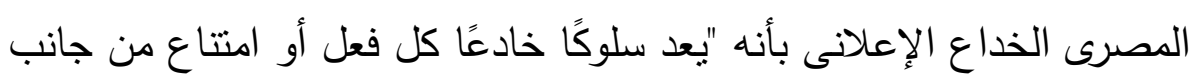

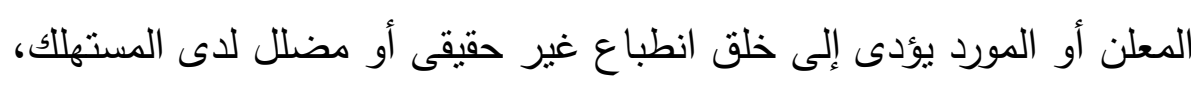

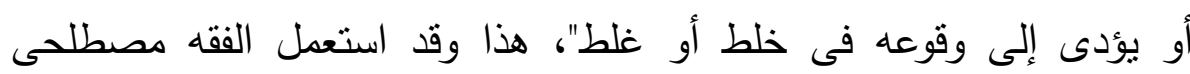

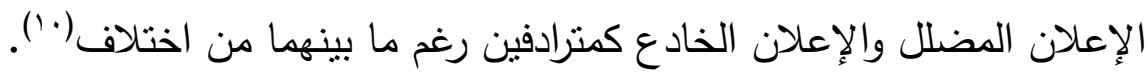


يتعين على الأطباء فى الأنظمة المقارنة توخى الابتعاد عن الإعلان أو أو الطئ

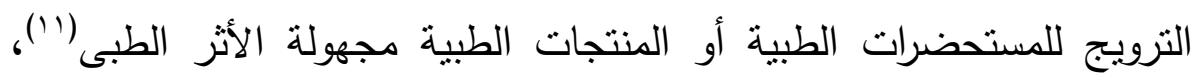

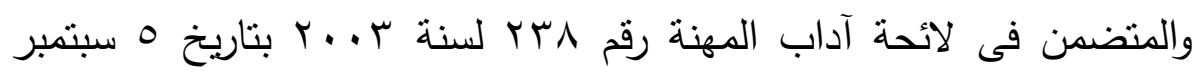

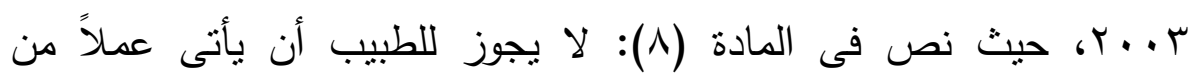

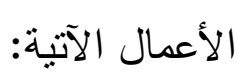

أ- الاستعانة بالوسطاء في مزاولة المهنة سواء كان ذلك بأجر أو بدون أجر .

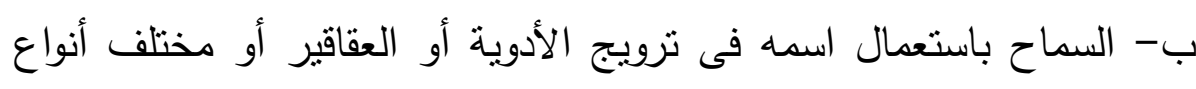

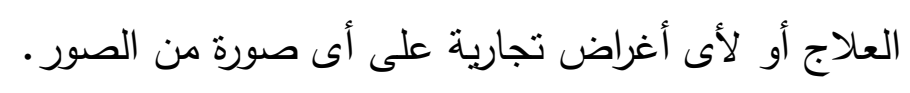

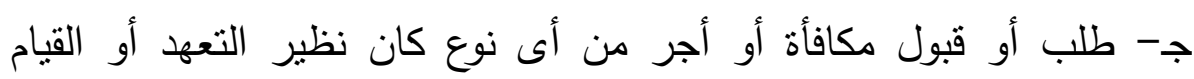

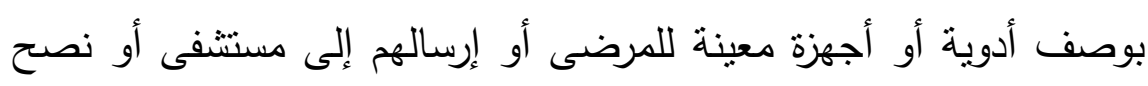

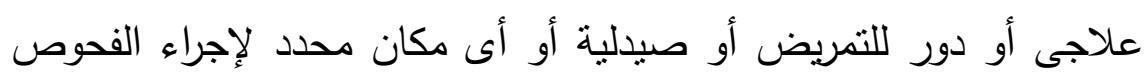

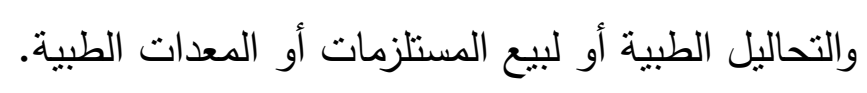

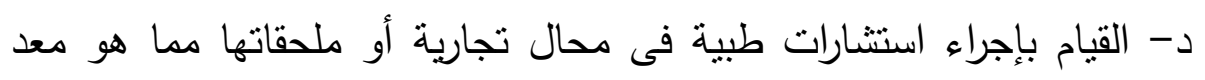

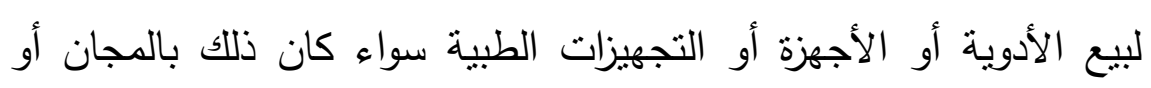
نظير مرتب أو مكافأة. هـ - القيام باستشارات طبية من خلال شركات الاتصالات.

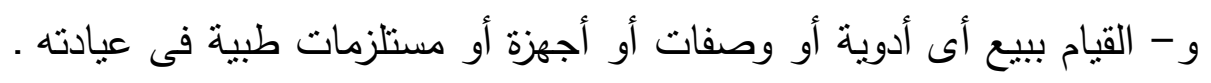

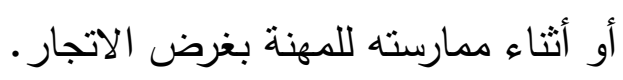

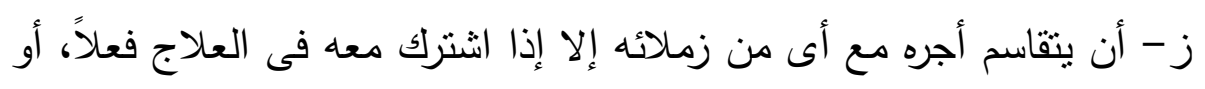

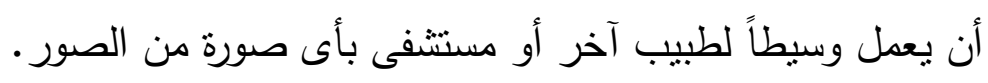

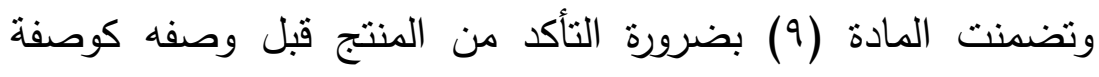

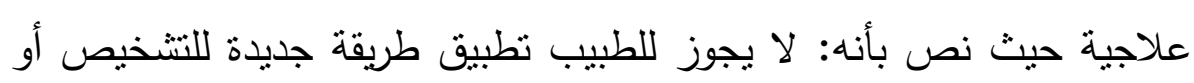


العلاج إذا لم يكن قد اكتمل اختبارها بالأسلوب العلمى والأخلاقى السليم

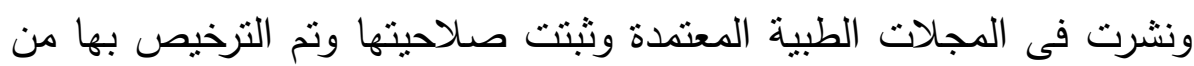

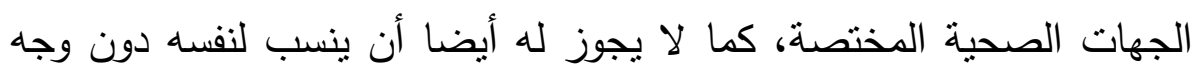

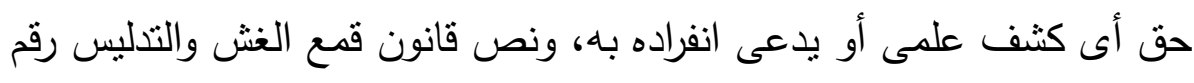

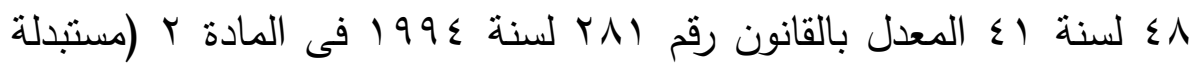

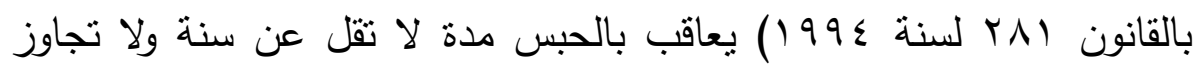
خمس سنوات وبغرامة لا تقل عن عشرة آلاف جنيه ولا تجاوز ثلاثين ألف جنيه

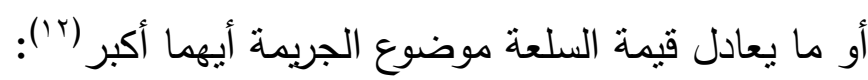

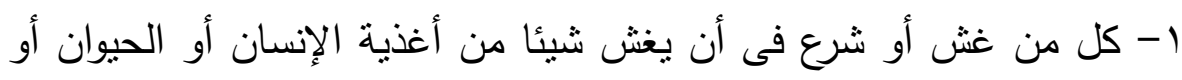

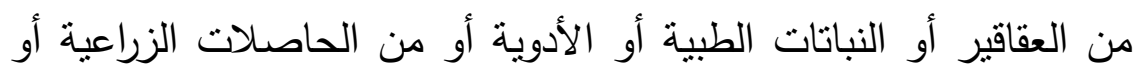

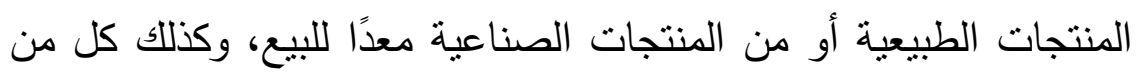

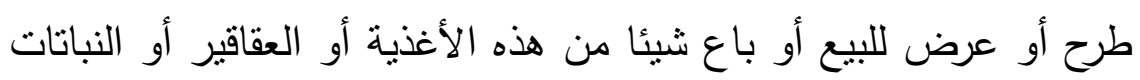

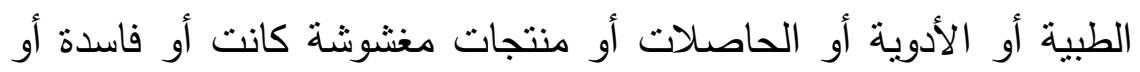
انتهى تاريخ صلاحيتها مع علمه بذللك.

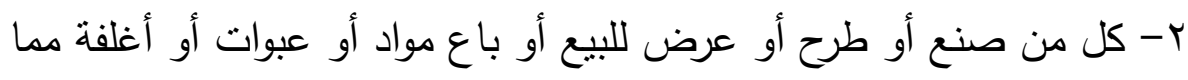
يستعمل فى غش أغذية الإنسان أو الحيوان أو العقاقير أو البيانات الطبية

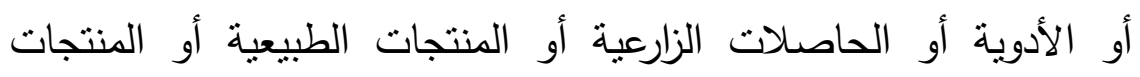

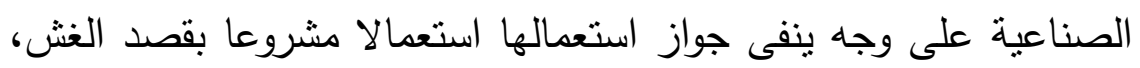
وكذلك كل من حرض أو ساعد على استعمالها فى الغش بواسطة كراسات

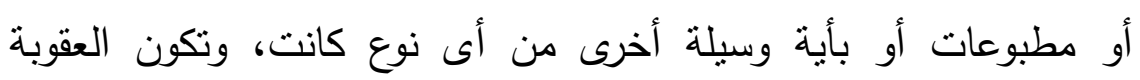

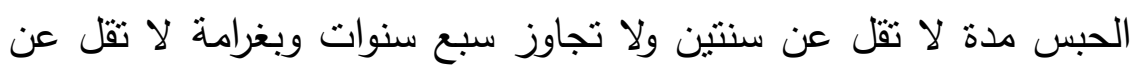
عشرين ألف جنيه ولا تجاوز أربعين ألف جنيه أو ما يعادل قيمة السلعة 
موضوع الجريمة أيهما أكبر • إذا كانت الأغذية أو العقاقير أو النباتات

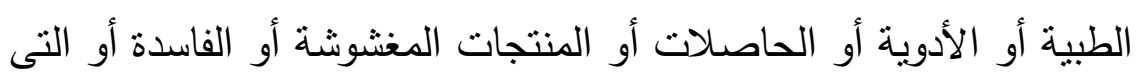

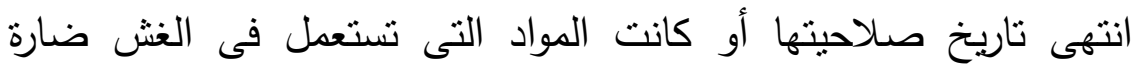

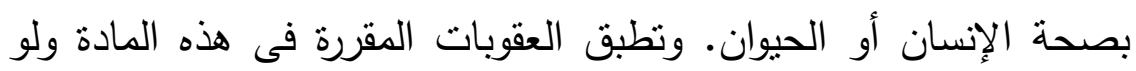
كان المشترى (المستهلك) عالما بغش البضاعة أو بفسادها، أو بانتهاء تاريخ صلاحيتها.

\section{أ- صور الوهم أو الخداع الإعلانى}

لم يقصر الفقه والقضاء مفهوم الخداع الإعلانى على صورة واحدة بل ميز بين عدة صور للذداع الإعلانى، وذللك على التقصيل التالى:

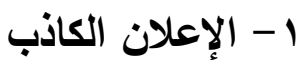

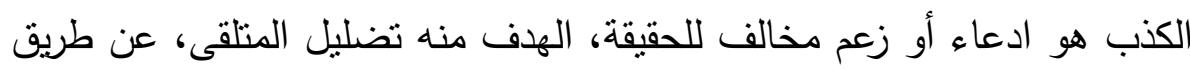
تزييف الحقيقة، لخداع المستهلك بتقديم بيانات غير حقيقية عن منتج أو خدمة

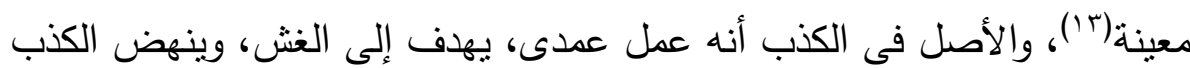
على عنصرين هما: مضمون زائف، وقصد الغش أو نية تزييف الحقيقة (؛ (1). وجدير بالذكر أن المشرع الفرنسى لم يستخدم صراحة لفظ الكنب فى نص المادة إY من تقتين الاستهلاك، وإن كان قد استخدم للتعبير عنه لفظ الإيهام والخطأ، ورغم التشابه بين هذه الاصطلاحات إلا أن الفقه يفضل اصطلاح الكذب فى التعبير عن فحوى الإعلان الكاذب لسببين الأول: أنه الإنه

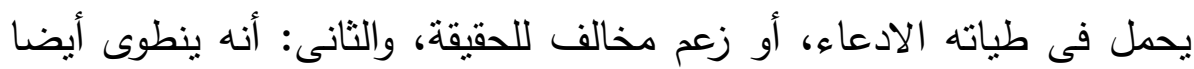
على معنى الخداع، والمعلن فى إعلانه يرمى إلى خداع متلقى الإعلان (10). 
ولذلك فإننا نرى أن الإعلان الكاذب وفقا لمفهوم المادة اب|-1 من

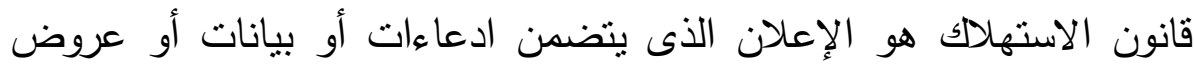
تاقض الحقيقة بقد خداع المستهلك، وهذا الإعلان الكاذب، جرمه هذا النص

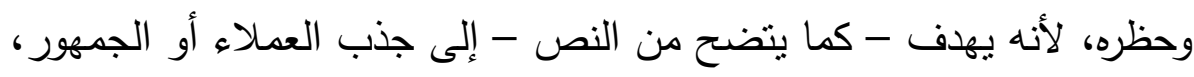

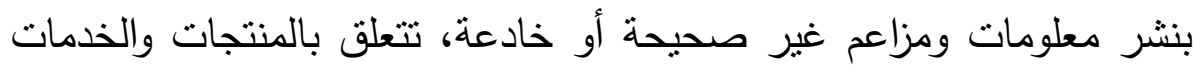

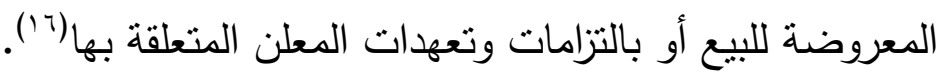

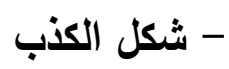
الكذب الإيجابى: يمكن أن يتحقق الكذب بفعل إيجابى من المعلن، وذلك حينما

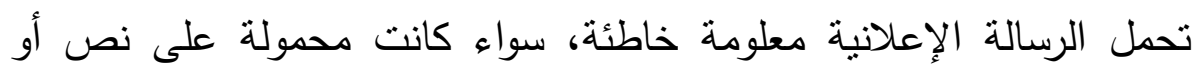
صورة أو ما إلى ذلك ('v'). وفى هذا الصدد قرر القضاء الفرنسى تحقق الكذب فى الإعلان عندما

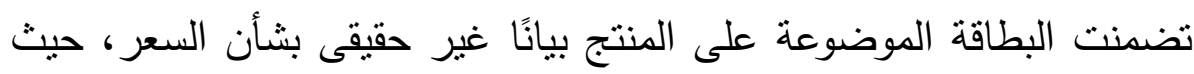
أثر ذلك فى إقناع العملاء بالمنتجات والخدمات الواردة بالإعلان (^)'. الكنب بالترك: يتحقق الكذب بالتزك أى باتخاذ موقف سلبى، يمتتع فيه

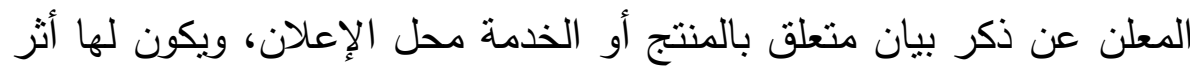
فى اتخاذ قرار الثراء، إذ أن ذكر نصف الحقيقة وترك النصف الآخر يعد كذبًا

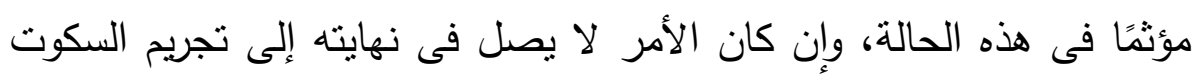
عن الحقيقة فى الإعلانات، فالحقيقة الموضوعية الكاملة غير موجودة فى الهى

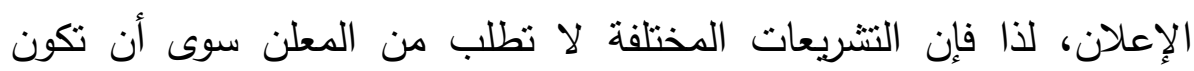
إعلاناته كاذبة أو مضللة، دون أن تتطلب منه أن يقول الحقيقة كاملة بإبراز 


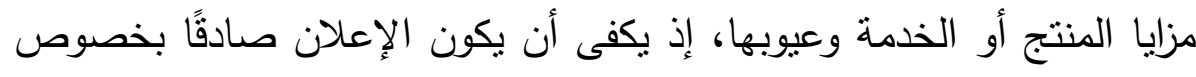

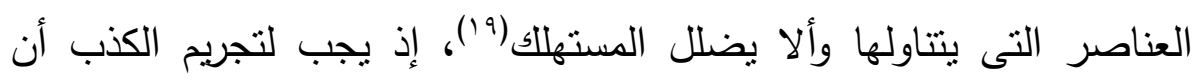
يكون له وجود موضوعى بحيث يمكن تقديره بمعيار موضوعى عام، وذلك بصرف النظر عن حسن أو سوء نية المعلن.

\section{r- ب الإعلان المضلل أو الخادع}

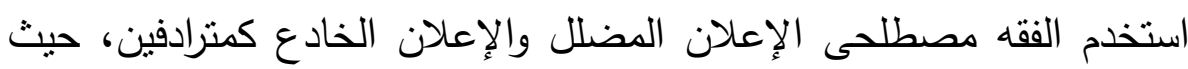

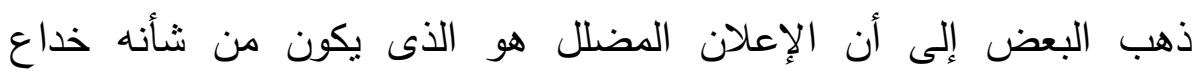

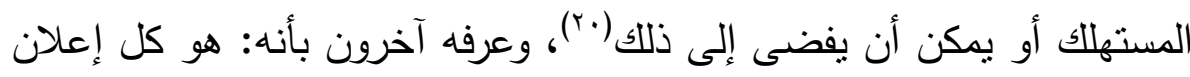

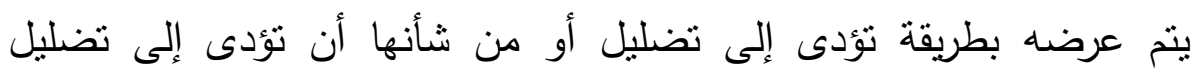
المخاطبين به، أو المنافسين على نحو قد بلى بلحق ضررًا بمصالحهم

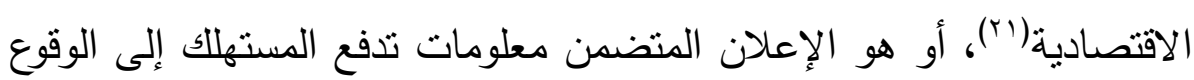

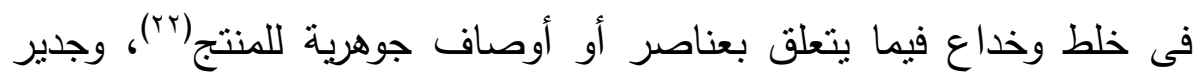

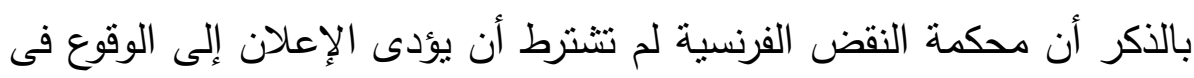

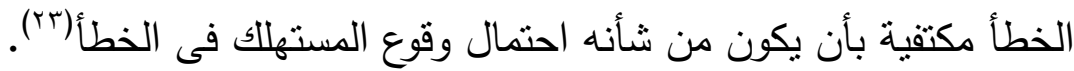

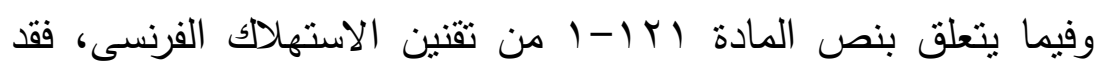

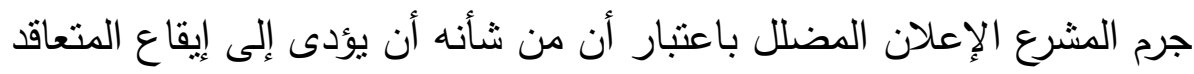

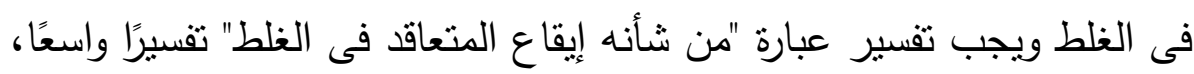
بحيث يدخل فى نطاق التجريم، الإعلانات التجارية الصحيحة فى ذاتها وفى لئى

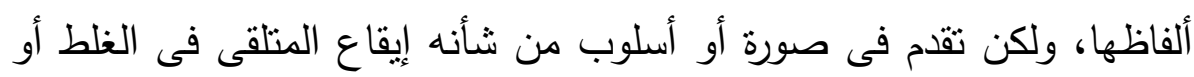
من شأنه الإيهام بوجود عناصر لمنتج أو لخدمة لا نتوافر فيه(بء). 
ولا جدال فى أنه إذا كان من الممكن تمييز كل من الإعلان الكاذب

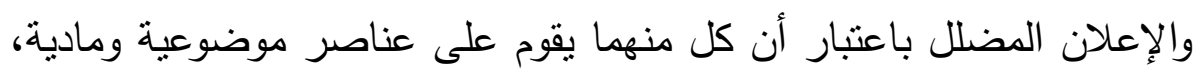
فإن الأمر يكون بالغ الصعوبة فى الإعلان الذى يمكن أن يؤدى إلى التضليل

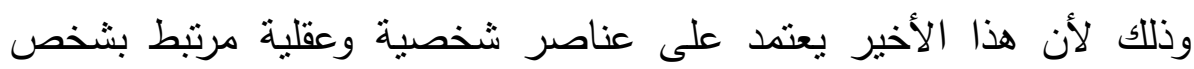
المتلقى ومدى استجابته للإعلان، وهى مسألة تختلف من شخص إلى آلى آخر (ror)،

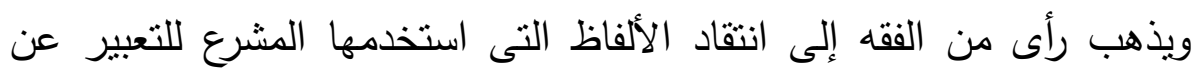
الإعلان المضلل، لعدم انضباطها وسماحها بالعديد من التأويلات، والتفسيرات المتفاوتة، وكان الأجدر به استخدام لفظ واحد أكثر تحديدًا.

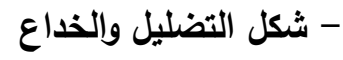
تتعدد الطرق التى بستخدمها المعلنون لإخفاء بعض الحقيقة عن المستهلك

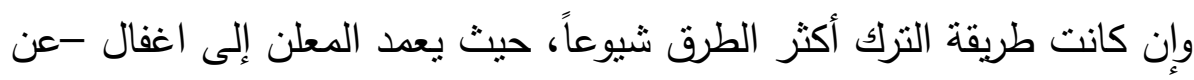
عمد أو سهو - بعض البيانات الجوهرية فى التعاقد الذى يريد حث الجمهور عليه، بحيث يتضخم مزايا التعاقد بالنسبة للعميل، أو يخفى بعض التزاماته(rV)

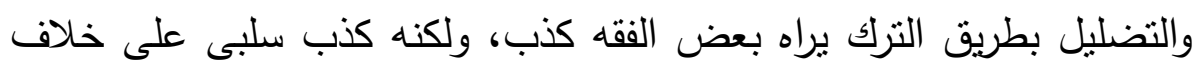

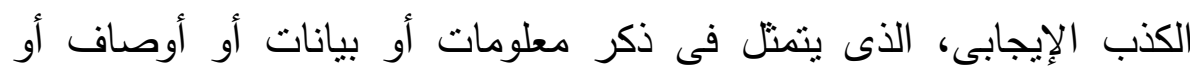
خصائص أو وقائع غير صحيحة، والأثز واحد فى الحالثين(r/). هذا وقد حفل القضاء الفرنسى بالعديد من الأحكام التى قرر فيها إدانة المعلن لاتباعه سلوكًا إيجابيًا، أدى إلى تضليل المستهلك أو أو لتركه بيانًا جوهريًا أدى إلى وقوع هذا الأخير ضحية للتضليل. 
ونسوق منها إدانة الإعلان الذى أغفل - عند الإعلان عن تأمين خطر

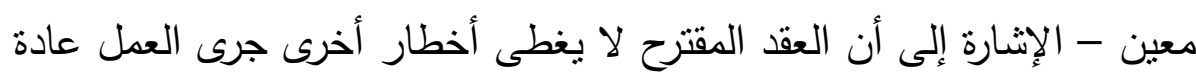
على تغطيتها (99).

\section{ب- الإعلان المبالغ فيه}

إذا كان الكذب غير جائز فى مجال الإعلانات، فإن المبالغة فى الإعلان عن

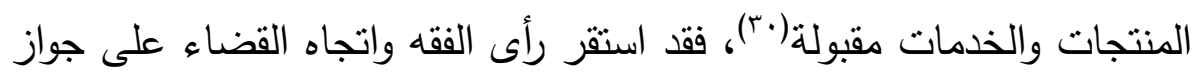

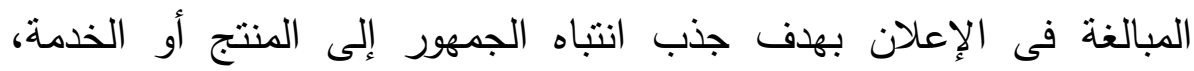
فامتداح المنتجات والخدمات، يفترض فى ذاته نوعًا من التجاوز المسموح به،

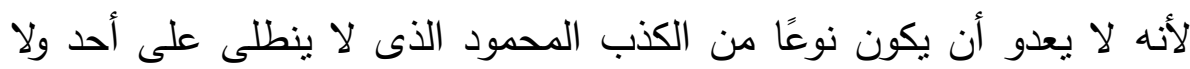

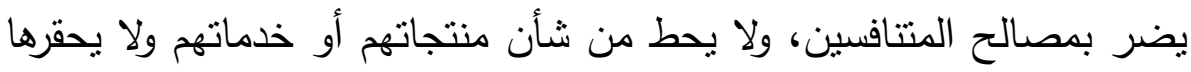

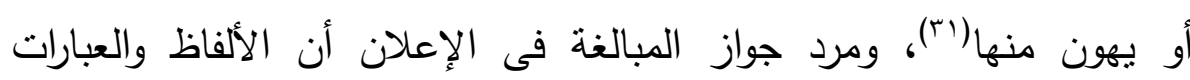

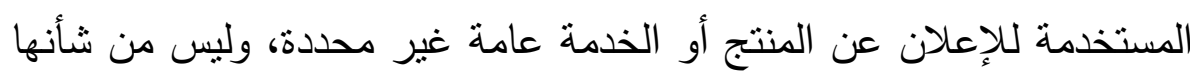

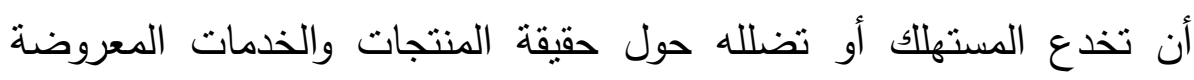
فيه (rr).

ومن أحكام القضاء التى أكدت على جواز المبالغة فى الإعلان ما قضت به محكمة النقض الفرنسية بصدد إعلان شركة حقائب سامسونيت؛

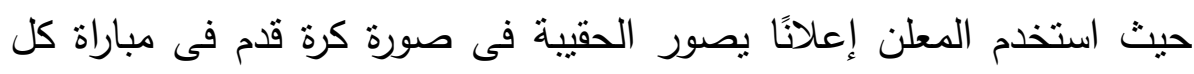
لاعبيها من البلدوزرات الضخمة، دون أن تتأثر هذه الكرة "الحقيبة" من ثقاذفها، وذللك بقصد إظهار منانة الإنتاج، ومع ذللك اعتبرت المحكمة هذه الحالة من

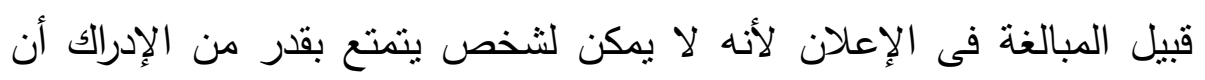


يعتقد بأن الكرة قادرة على الخروج من تحت هذه البلدوزرات سليمة(rr). ع - معيار التمييز بين المبالغة فى الإعلان وإلكنب وإلتضليل

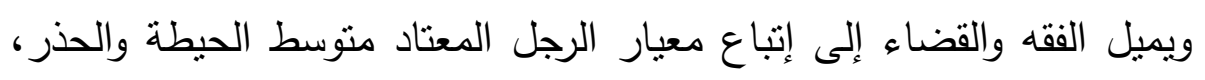

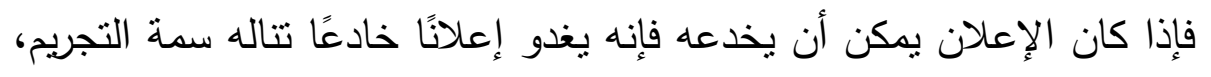

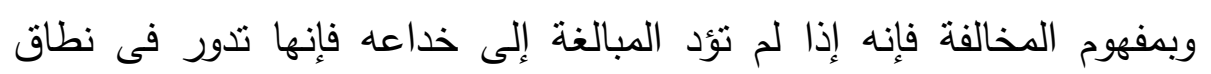
الإباحة ولا ينالها التجريم (عُّ).

ه- الإعلان المقارن ومدى اعتباره صورة من صور الإعلانات الخادعة

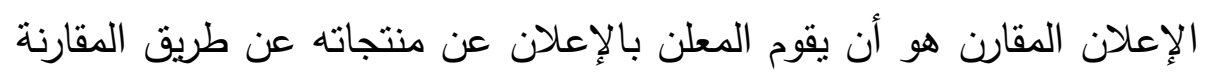

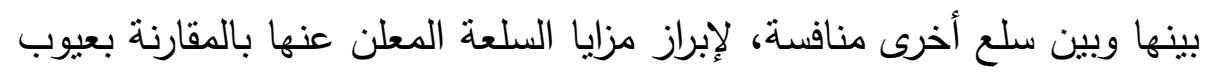

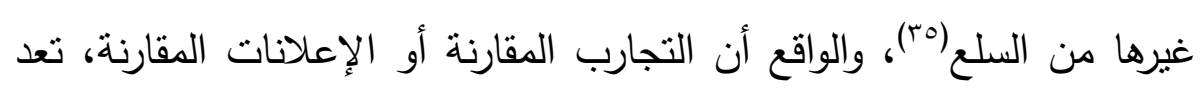

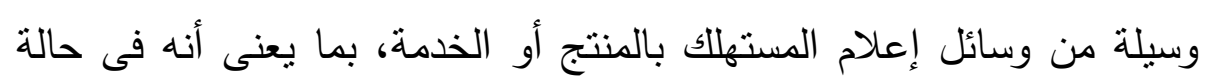

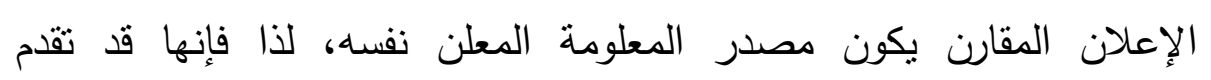
للمستهلك معلومات غير موضوعية أو على الأقل غير دقيقة، إذ يلجأ إليها

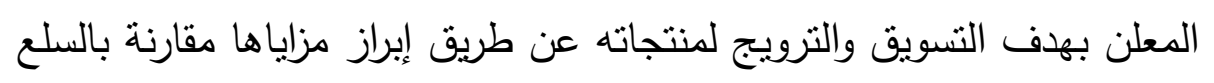
أو المنتجات المنافسة، ويحركه فى ذلك عامل تحقيق الأرباح التجارية(؟r).

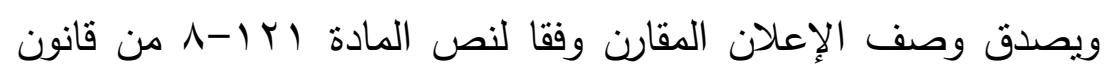

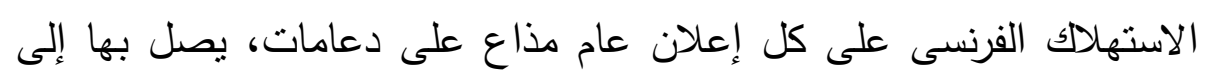

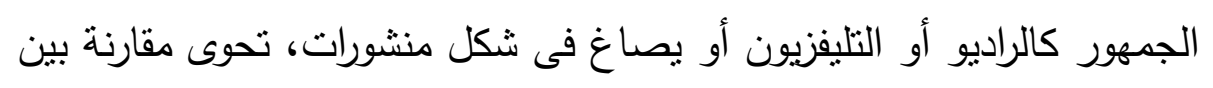

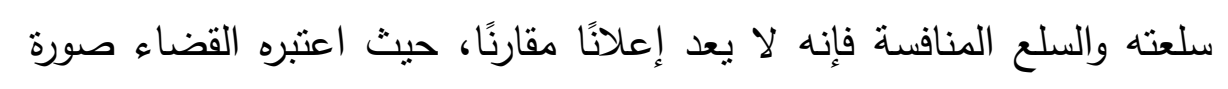

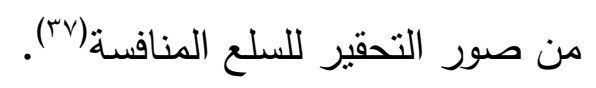


وفضلاً عن ذلك يحب أن يشتمل الإعلان على مقارنة لشىء محدد أو

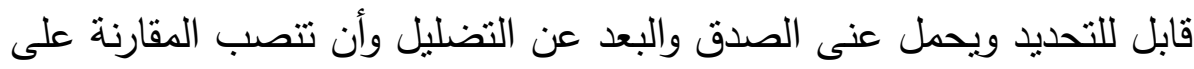

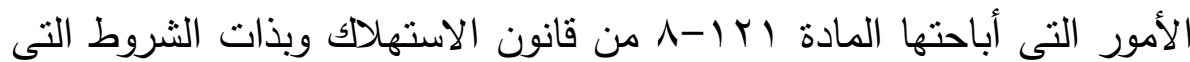
حددتها هذه المادة ولسلع متماتلة، إذ لا يعد إعلانًا مقارنا مقارنة منتج بمنتج

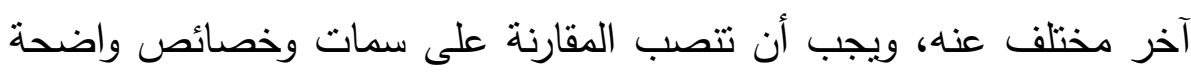
غير مهمة وأن تكون موضوعية عامة وليست ذانية التقدير. צ- تقييم حقيقة تأثير الإعلان المقارن على مصالح المستهلك

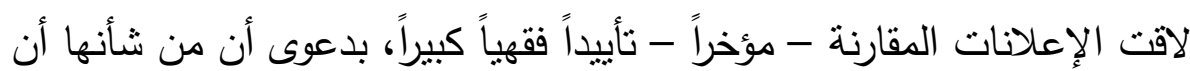
توفر معلومات حقيقية للمستهلك عن طريق المقارنة بين المنتجات المختلفة، ويذكر أن لجنة إعادة النظر فى قانون الاستهلاك الفرنسى قد إنحازت بشدة للإعلان المقارن، وانتقدت موقف القضاء الذى كان يتسم بالثدة البالغة عند نظره لأى دعاوى خاصة بإعلانات مقارنة. ويرى الأستاذ Pirovana أن الإعلانات التجارية المقارنة تحقق مصالح باعتهات المستهلك، وتكفل له العلم بصورة كاملة وموضوعية، إذ انصبت الإعلانات على عناصر حقيقية، تتعلق بخصائص المنتج وثمنه وسلامة استعماله مقارنة بالمنتجات الأخرى، إذ إن علم المستهلك بهذه العناصر يكفل له حسن الاختيار

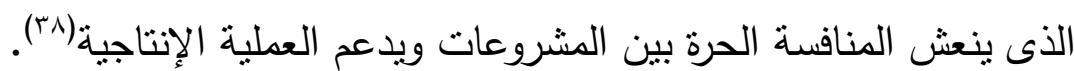
هذا وقد أيد المشرع الفرنسى الاتجاه الفقهى الحديث الذى يتسم بالانحياز للإعلان المقارن، ونص فى قانون 11 يناير ب999 على إجازة الإعلانات

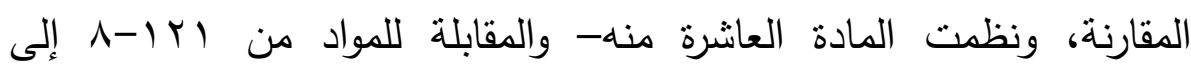


اب ا/ ا من تقنين الاستهلاك الفرنسى- ضوابط الإعلان المقارن وقيوده

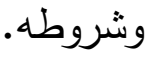

ومن جانبنا فإننا نرى أن الإعلان المقارن لا يعدو أن يكون وسيلة من

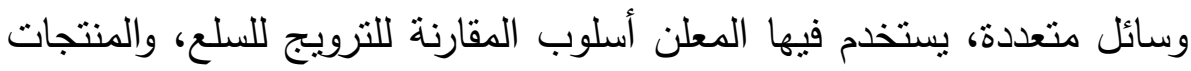
والخدمات، فإذا انسمت هذه المقارنة بقدر من الكذب أو الخداع والتضليل فإن

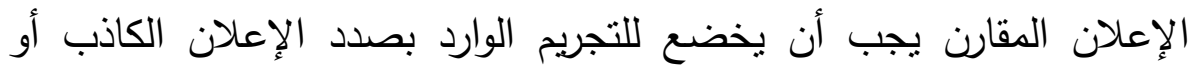
الخادع والمضلل، وغيره من القوانين المعنية كقانون الملكية الفكرية، هذا فضلا عما يشكله من منافسة غير مشروعة تستوجب التصدى لها بنصوص خاصة.

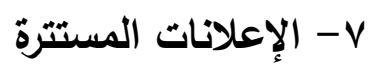

يقتى الإعلان أن يكون المستهلك على علم بأن المادة التى ينم توجيهها إليه، عبارة عن إعلان تجارى يهذف إلى الترويج والتسويق لسلعة أو خدمة ما،

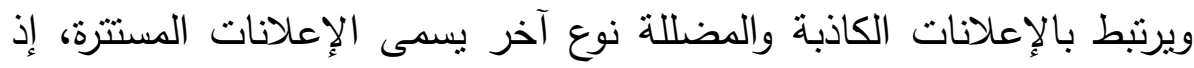
يلاحظ أن بعض الإعلانات فى الصحف والمجلات نتخذ صورة مستتزة، من

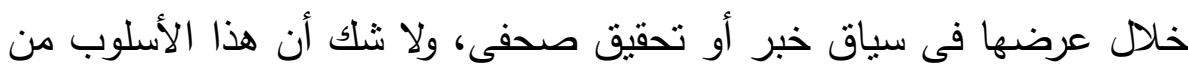
شأنه فى أحيان كثيرة تضليل الجمهور • 1- مدى شمول تجريم الإعلانات الخادعة لصورة الإعلانات المستترة وحقيقة فإن كل من المشرع المصرى والفرنسى لم يجرم الإعلانات المستترة بنص خاص، وإن كان المشرع الفرنسى حارب هذه الصورة بطريق غير مباشر فى الأمر الصادر فى بr أغسطس ؟ ؟9 1، الذى أوجب على جهة الإعلان

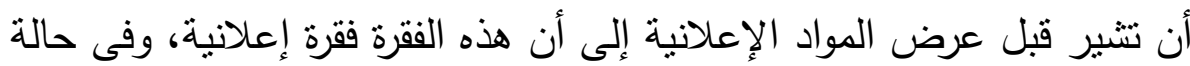


مخالفة هذا الالتزام يعاقب المخالف بعقوبة الحبس التى تتراوح بين ستة أيام وستة أشهر والغرامة أو إحدى هاتين العقوبتين(ج9).

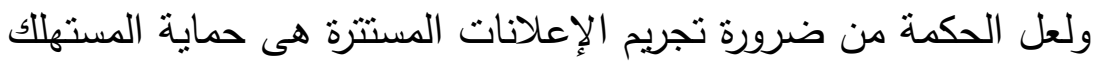
من إخفاء عناصر هامة، يكون لها تأثيرها فى تكوين عقيدته، ومن شأنها إيقاعه فى الخداع حال حجبها عنه، كما تبرز أهمية تجريم الإعلانات المستترة فى أنها تتضمن الكذب على المستهلك مرتين الأولى عندما توهمه بأن ما يتلقاه

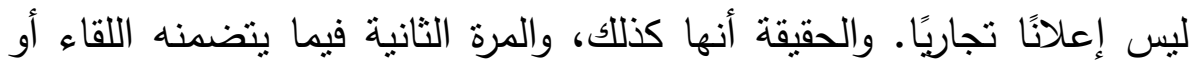

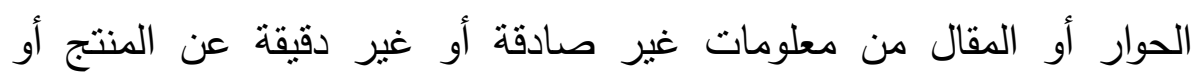

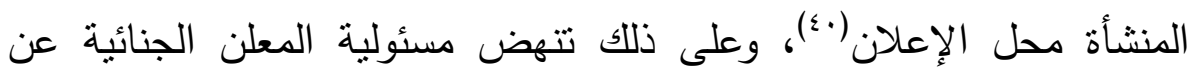
الإعلانات المستترة على ما يشوبها من علامات مضللة، تفضى إلى غش وخداع المستهلك، فهى إعلانات غير قانونية حتى وإن تضمنت معلومات حقيقية وصادقة(1)، وفضلا عن ذلك فإن الإعلانات المسنترة قد تكون مجالاً

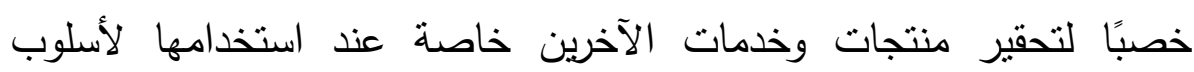
المقارنة، وجدير بالذكر أن لجنة تعديل قانون الاستهلاك قد انتهت عند التهات

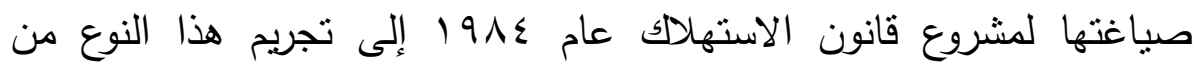

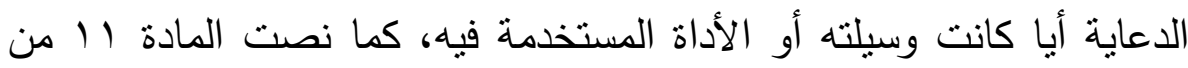
التقنين الدولى للعمليات الصادقة على إدانة هذا النوع من الإعلانات، ووضعت

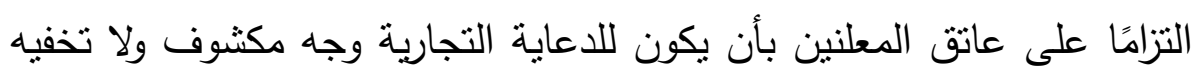

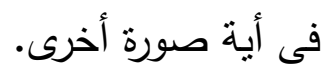


9- صور الخداع الإعلانى فى قانون حماية المستهلك المصرى استجاب المشرع المصرى على استحياء لنداءات طالبته بالتدخل لمواجهة ظاهرة الخداع الإعلانى، وبصدور قانون حماية المستهلك رقم VT لسنة ج +. T بمكن القول بأن هذا القانون قد تصد لمسألة كفالة التقة وضمان المصداقية فى المعاملات التجارية التى تتم بين المنتجين والموزعين والمعلنين من ناحية والمستهلكين من ناحية أخرى من خلال تأكيده - بنص المادة الثالثة - على حق المستهلك فى الإعلام قبل التعاقد كضمانة لصدور رضناء صحيح من قبله. كما ألقى على عاتق الموزع والمعلن عند الإعلان عن منتجاته أو خدماته الالتزام بالصدق والموضوعية فى كل ما يتتاوله الإعلان عن المنتج أو الخدمة، واعتبر أى مخالفة لهذا الالتزام تشكل تضليلاً للمستهلك وفقا لما نصت عليه المادة السادسة من القانون سالف الذكر . وحدد المشرع فى المادة السادسة من قانون حماية المستهلك صور الخداع الإعلانى، حيث نصت على أنه "على كل مورد ومعلن إمداد المستهلك بالمعلومات الصحيحة عن طبيعة المنتج وخصائصه، وتجنب ما قد يؤدى إلى خلق انطباع غير حقيقى أو مضلل لاى المستهلك أو وقوعه فى خلط أو غلط".

ويتبين من هذا النص أن المشرع أورد عدة صور للخداع الإعلانى، وهى الإعلان الكاذب الذى يؤدى إلى خلق الانطباع غير الحقيقى لدى الأفراد، والإعلان المضلل الذى لا يحتوى على صورة من الكذب ولكن يصاغ بشكل يؤدى إلى تضليل المستهلك وبالتالى وقوعه فى خلط أو غلط. 


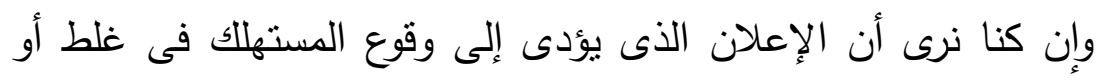

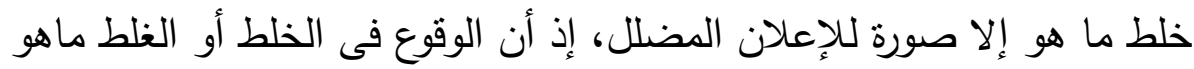

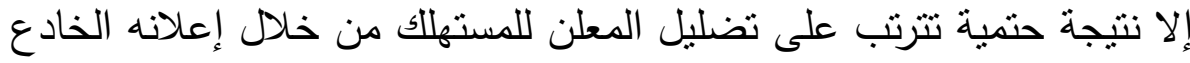

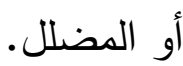

ويرى البعض فى هذا الصدد أن الفارق بين الإعلان الكانب من جانب والإعلان المضلل والخادع من جانب آخر ، يكمن فى أن الأخيرين لا يتضمنا

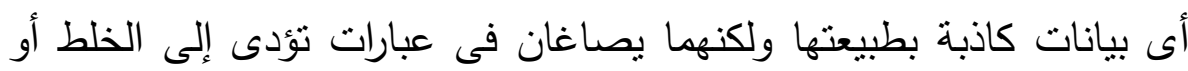

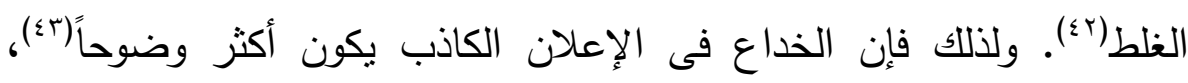

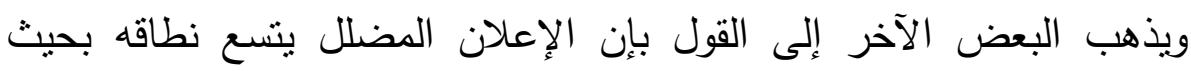

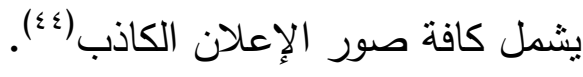
ـ 1 - موقف المشرع المصرى من الإعلانات المستترة يثور التساؤل حول ما إذا كانت عبارات المادة السادسة من قانون حماية

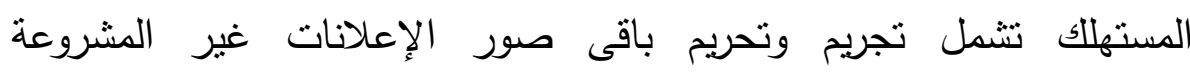
كالإعلانات المستترة والمقارنة أم لا؟ وعلى ما يبدو من ظاهر هذه المادة أنها لم تحرم سوى الإعلانات الكاذبة أو أو العان

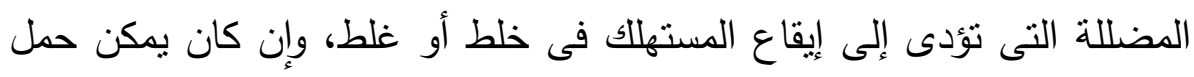
تحريم الإعلانات المقارنة حال تضمنها لما يخالف مقتضيات حماية الدستهلك

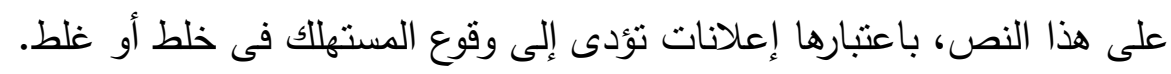
ولكن تظل الإعلانات المستترة بمنأى عن التجريم إذ إن أولى مفترضات التهات

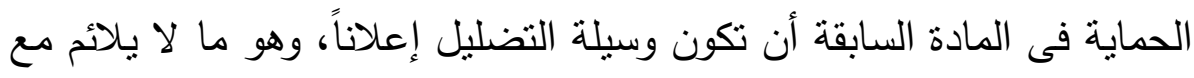


طبيعة الإعلانات المستترة التى لا تتذذ أبدا وصف الإعلان الظاهر.

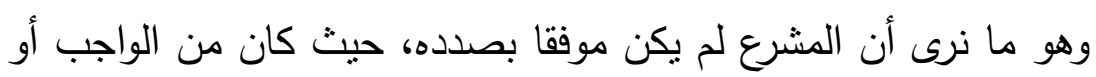

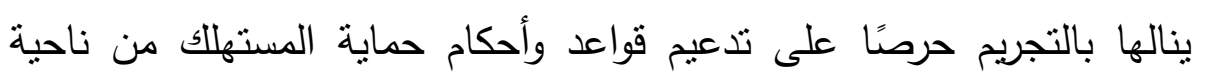

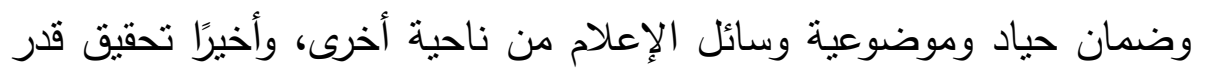

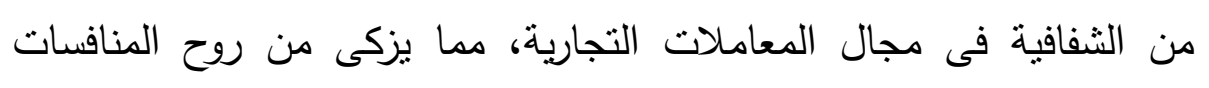

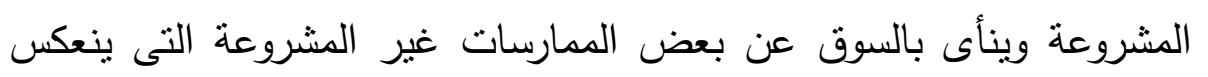
مردودها السلبى على كافة أطراف السوق.

ويؤكد وجهة النظر السابقة ما نصت عليه المادة 17 من اللائحة

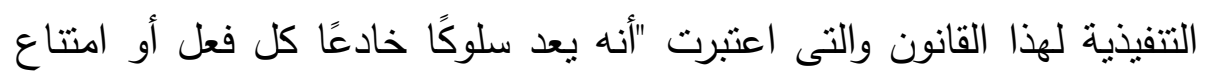

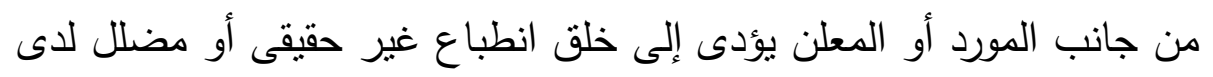
المستهلك أو يؤدى إلى وقوعه فى خلط أو غلط".

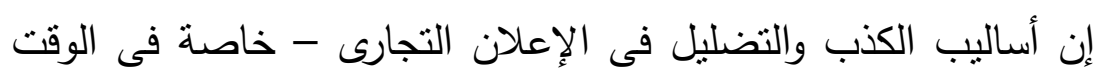

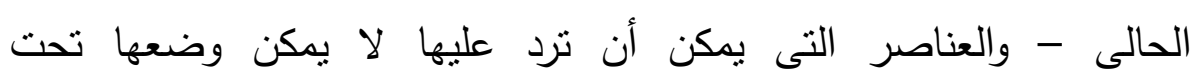

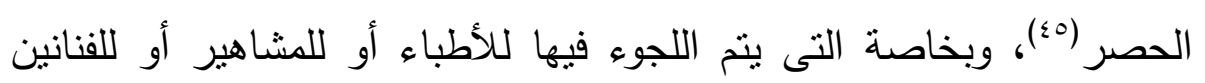

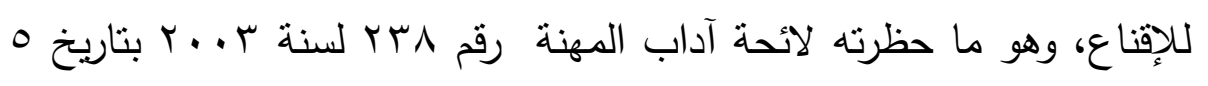

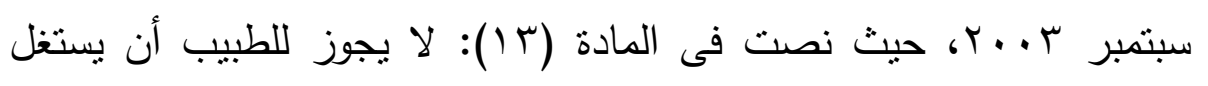
وظيفته بقصد تحقيق منفعة شخصية أو الحصول على كسب مادى من

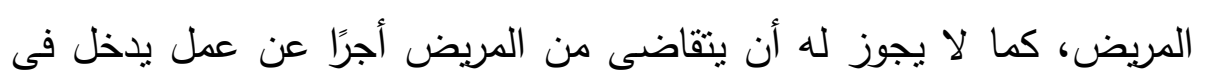

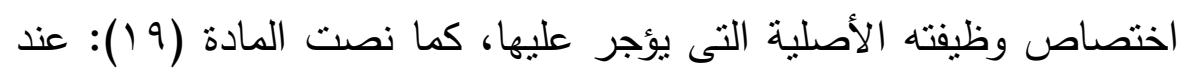
مخاطبة الجمهور فى الموضوعات الطبية عبر وسائل الإعلام يلتزم الطبيب 
بالقواعد الآتية:

أ- تجنب ذكر مكان عمله وطرق الاتصال به والإشادة بخبراته أو إنجازاته العلمية، ويكتفى فقط بذكر صفته المهنية ومجال تخصصه.

ب- أن تكون المخاطبة بأسلوب مبسط يلائم المستمع أو المشاهد غير ولهاه المتخصص.

ج- تجنب ذكر الآراء العلمية غير المؤكدة أو غير المقطوع بصحتها، أو تتاول الموضوعات المختلف عليها والتى يكون مناقتنها فقط فى الجلسات

العلمية الخاصة غير الموجهة للعامة.

ولم يمنع ذلك بصفة عامة فى الأنظمة المقارنة من تجريم الإعلانات

الخادعة وفقا لأنظمة حماية المستهلك ومنها ما قرره المشرع الفرنسى - فى قانون الاستهلاك - أو المصرى - فى قانون حماية المستهلك - من السعى نحو محاولة تحديد هذه العناصر، وذلك بمقتضى نص المادة اYI-1 من قانون الاستهالك الفرنسى الصادر فى عام ب991 والتى تمنل فى جوهرها محل الكذب والتضليل فى الإعلان التجارى، أو بمقتضى نص المادة السادسة

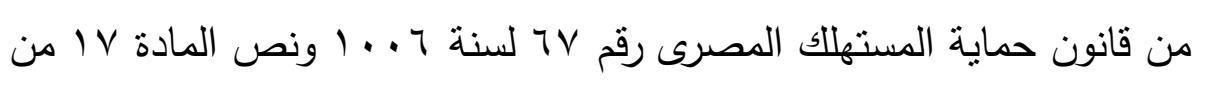
اللأحة التنفيذية لهذا القانون والتى نصت على أنه "يعد إعلاناً خادعا الإعلان الذى يتتاول منتجًا ويتضمن عرضًا أو بيانًا أو ادعاء كاذبًا، أو أى أمر آخر ينصب بصفة خاصة على عنصر من العناصر التى حددتها هذه المادة متى كان من شأنه أن يؤدى بطريقة مباشرة أو غير مباشرة إلى خلق انطباع غير حقيقى أو مضلل وأيا كانت وسيلة هذا الإعلان. 


\section{ثانيا: مكم عطايا الأطباء}

إن ملاك العمل فى الحقل التجارى قائم على تحقيق أعلى مكاسب مادية ، دون

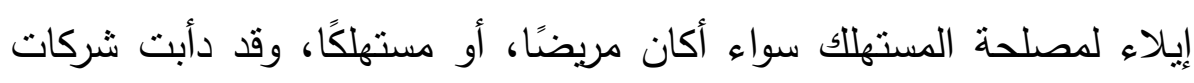

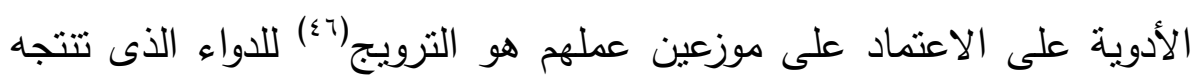

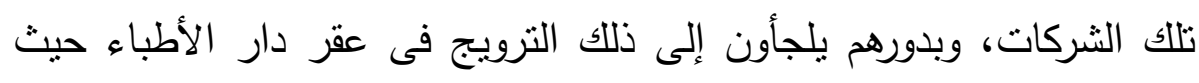
أماكن عمهم العام والخاص وتعريفهم بالأدوية التى يوزعونها وتحفيزهم ماليًا

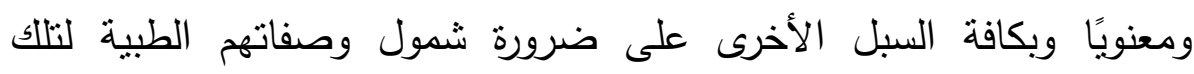

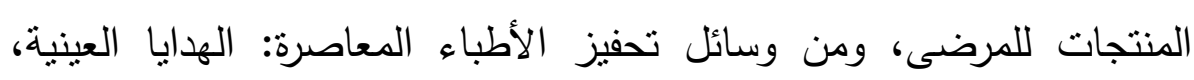

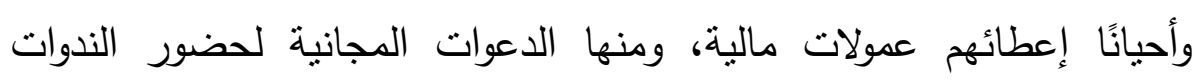
العلمية، واستضافتهم إلى أماكن التزفيه أو الاستشفاء، ونحو ذلك، وفئه وفى أحيان

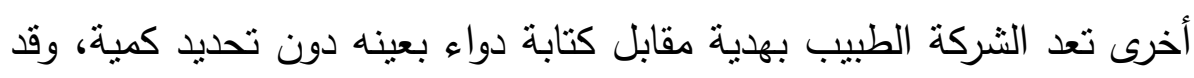

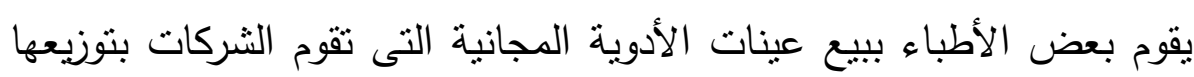

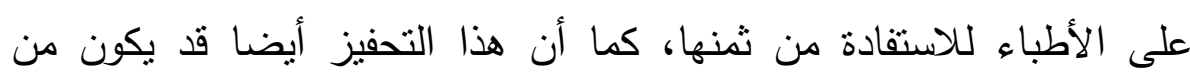

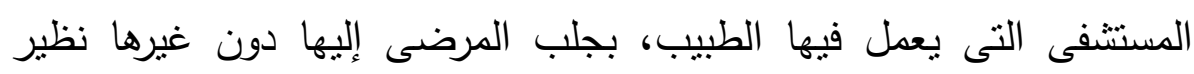

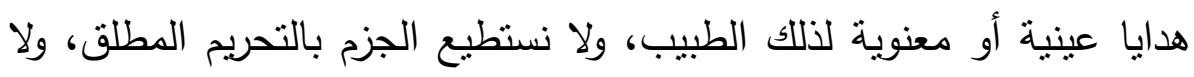

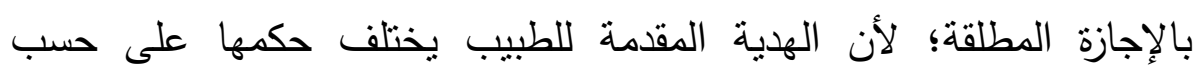

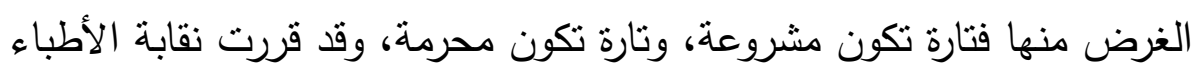

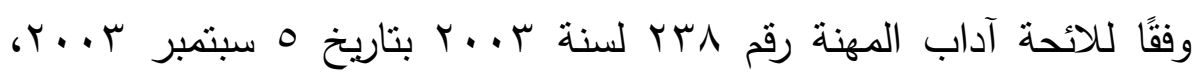

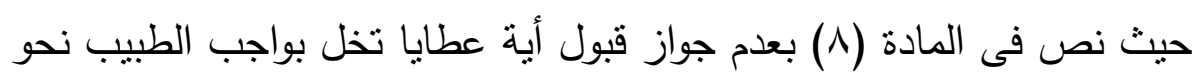

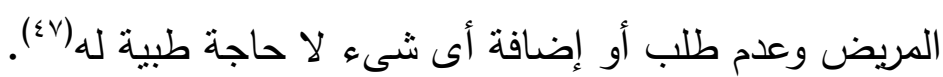

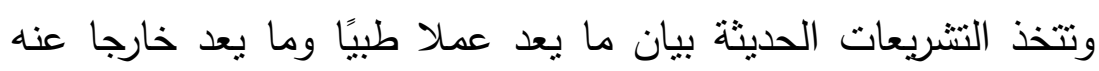

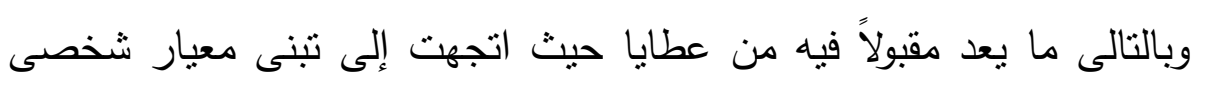


وآخر موضوعى من حيث تحديد نطاق ومضمون العمل الطبى، فيعد العمل طبيًا، وفقًا لهذه الاتجاهات، كل من يباشر بنفسه أو بواسطة غيره، أو بأية فئل

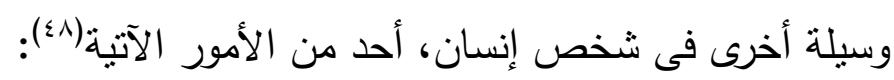

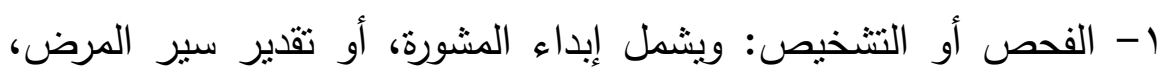

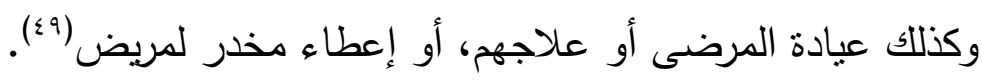

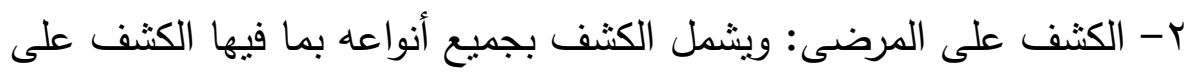

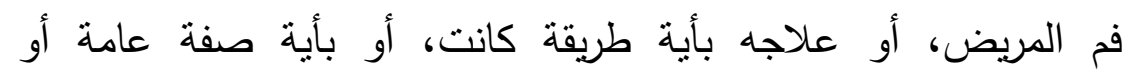

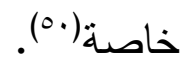

r- مباشرة العلاج النفسى على الإنسان: وهو مباشرة الطبيب النفسى العلاج فى الحالات الإكلينيكية الحادة التى تصيب المريض النفسى، وتهدد صحته بالخطر، أو سلامة الآخرين، وتتطلب التدخل الطبى العاجل (1). ع- إجراء العمليات الجراحية: وتشمل كافة العمليات بما فيها، عمليات الولادة،

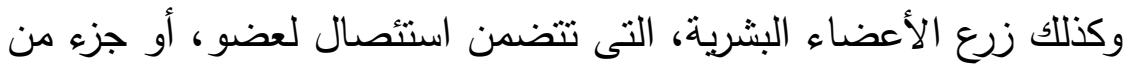

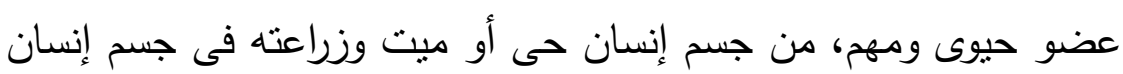
حى، بهدف المحافظة على حياته، أو لتحقيق مصلحة علاجية راجحة، مئه

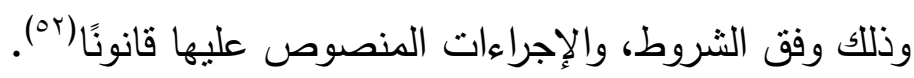
0- وصف أو إعطاء أدوية أو علاج : ويتضمن إعطاء علاج شاف والف، مهما

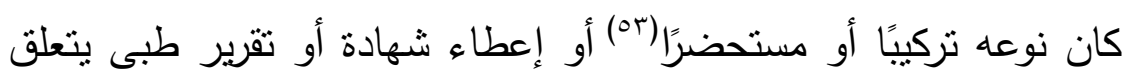

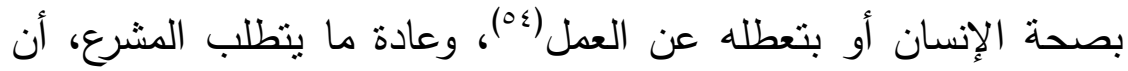

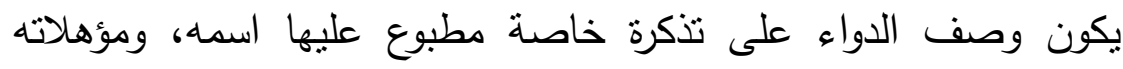
العلمية، وتخصصه إن وجد، كما يكتب عليها اسم المريض، والوصف بخط 
واضح، وبدون رموز، ويوقع عليها الطبيب، ويمكن أن تختم بختمه الخاص(00). (100.

7- وصف الأجهزة التعويضية: وتتضمن وصف النظارات الطبية، وسماعات

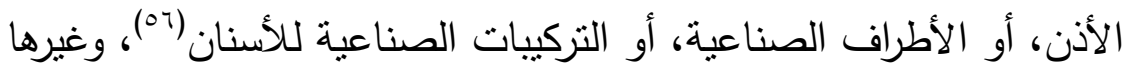
من الأعمال المشابهة.

- V أخذ العينات من جسم المرضى الآدميين للتشخيص الطبى المعملى:

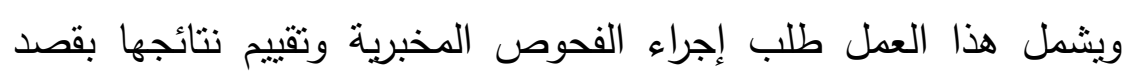

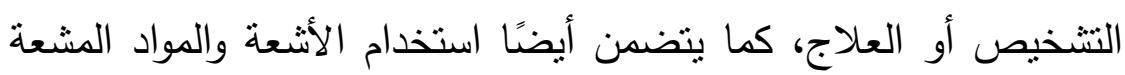
بأنواعها بقصد التتخيص والعلاج، وكذلك استخدام المواد الفيزيائية كالموجات الصونية والضوئية وغيرها من المواد بقصد النتخيص أو وكائ العلاج) الموجان (ov)

ᄉ-إجراء الفحوص الطبية الثرعية: وتتثل إجراء الصفة التشريحية لجثث الموتى أو إعطاء تقارير طبية بهذا الثنأن.

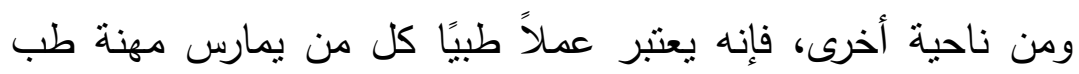

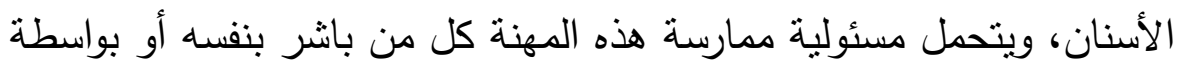
غيره أو بأية وسيلة أخرى فى شخص إنسان الخدان أحد الأمور الآتية:

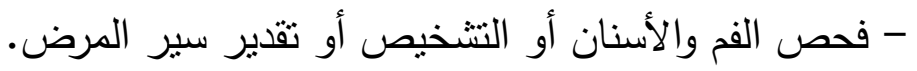
- وصف أو إعطاء علاج شاف أو واق للفم والأسنان مهما كان تركييًا أو الو لوضئ مستحضرًا. - مباشرة أى عمل طبى أو جراحى للفم.

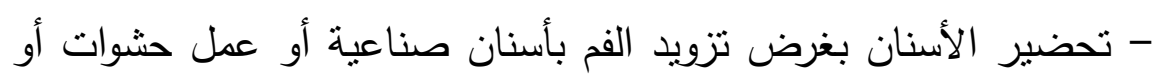
تيجان أو جسور أو غير ذلك. 
- أخذ قياسات بالفم بغرض تركيب أسنان صناعية.

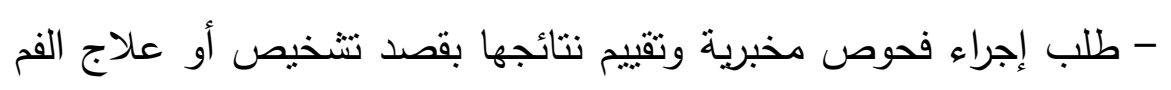
والأسنان.

- استخدام الأشعة والمواد المشعة بأنواعها بقصد تشخيص أو علاج الفم

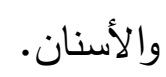

- استخدام المواد الفيزيائية كالموجات الصوتية والضوئية وغيرها من المواد

$$
\text { بقصد التشخيص أو العلاج. }
$$

- إعطاء شهادة أو تقرير طبى يتعلق بصحة إنسان فيما يخص الفم

والأسنان.

وأخيراً نشير هنا، فى هذا المقام، أنه لا يشترط فى وصف العمل

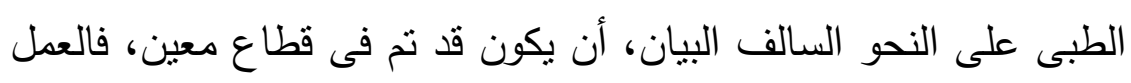

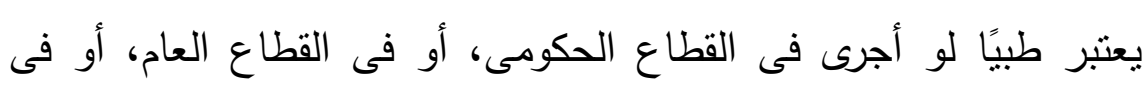

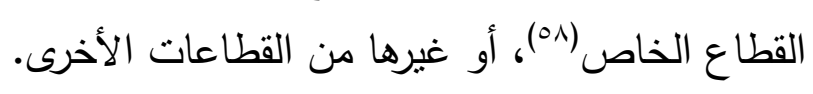

1- عطايا الأطباء لغرض ترويج السلعة، ولا أثر لها على المريض

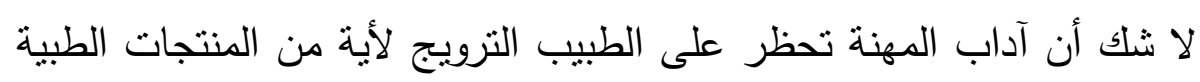

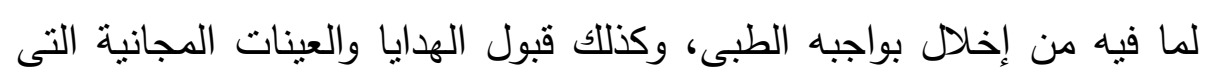

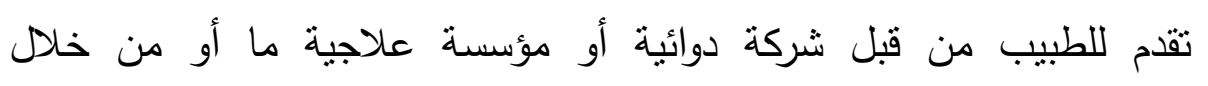

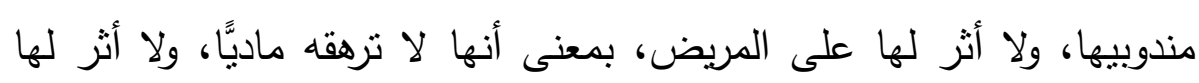

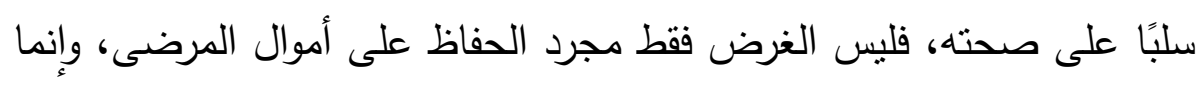

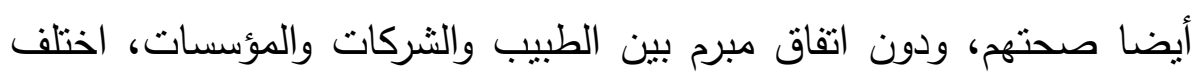
الفقهاء فيها على قولين بين مجيز ومانع. القول الأول: يرى عدم جواز الهدية المقدمة للطبيب من شركة منتجة 
للاواء سواء أكان لهذه الهية أثر على المريض أم لا، وذهب إلى هذا القول

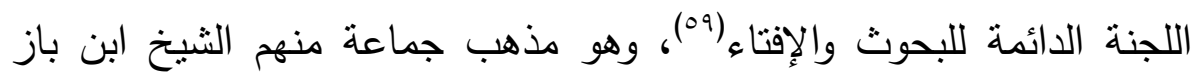

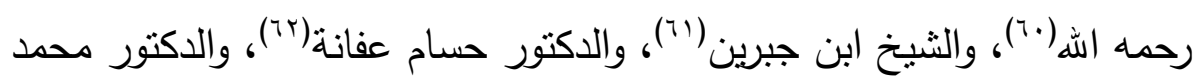
بن عبد الله الثبانى (بآ.

واستدلوا على ذلك: بأن الهدية هنا من باب الرشوة، ولو سميت بهدية أو

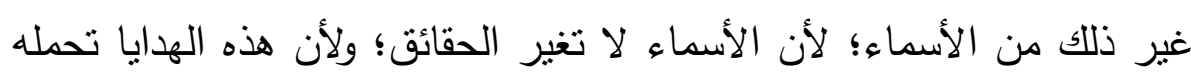

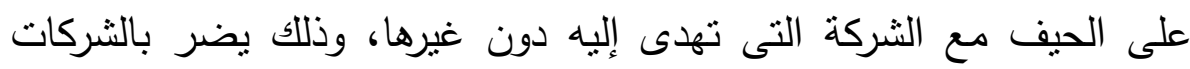

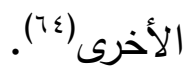
القول الثانى: يرى جواز العينات الدوائية المجانية المقدمة للطبيب من

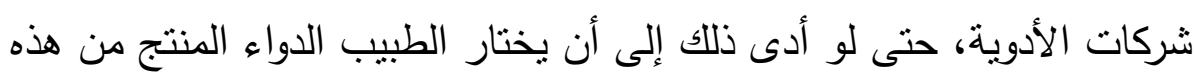

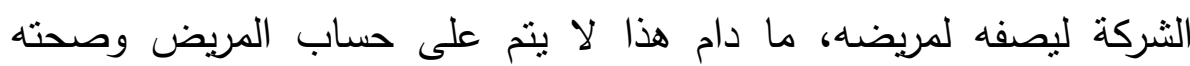

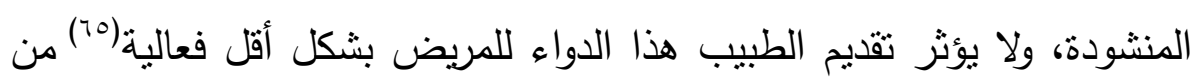

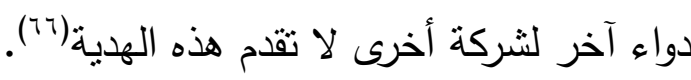

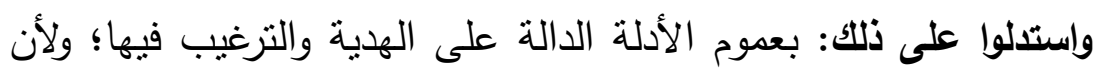
الهدية مطلوبة شرعا بشكل عام، والرسول عليه الصلاة والسلام قال: (تهادوا

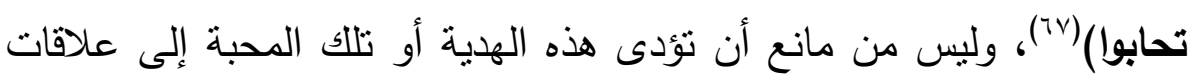

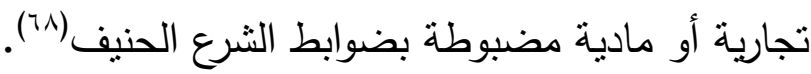

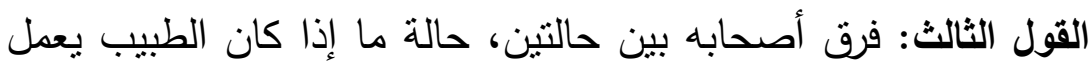

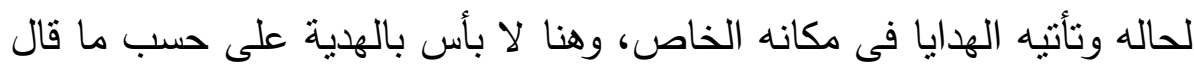

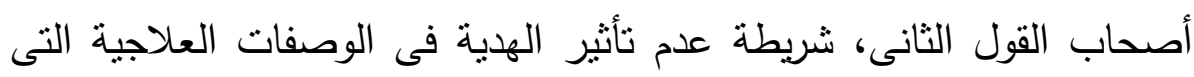

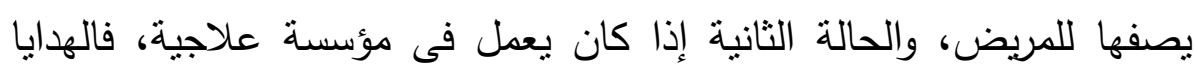

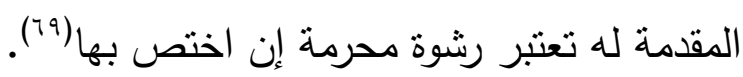




\section{واستدلوا على ذلك بأدلة، منها:}

أولا: إن الهدايا العينية والنقدية التى تقدمها الثركة المنتجة للدواء هى الثى الثى

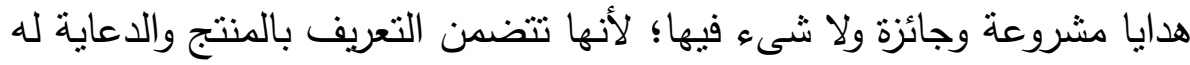

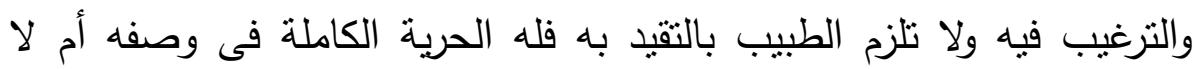

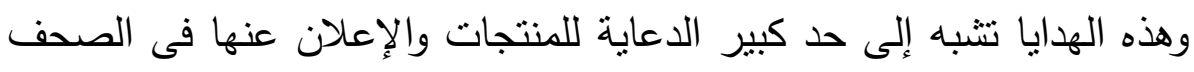
والمجلات ووسائل الإعلام المقروهة والمسموعة وكلها جائزة بشرط أن يلتزم صاحب الدعاية بالحقيقة فلا يغش ولا يغرر ولا يكذب فى التركيب والآثار (•vان.

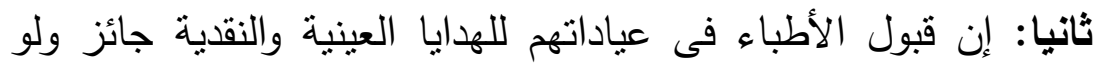
كان فيها مصلحة ومنافع للطرفين وذلك مثل سائر الهبات والعطايا ولا يلزم

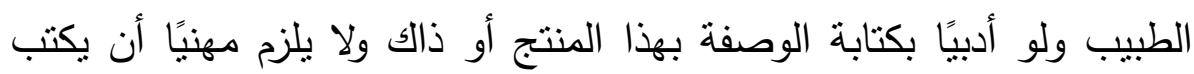

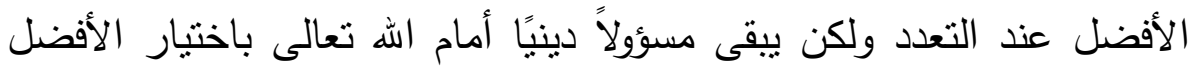
للمريض والنصح له، والتزام الدقة والكمال فى العمل.

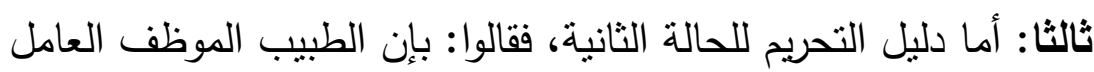

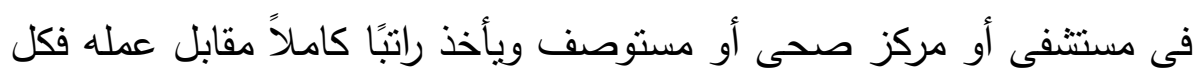

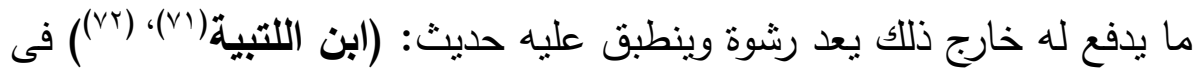
الرشوة ومعيارها (أفلا جلس أحدكم فى بيت أبيه أو أمه فينظر أيهدى إليه)،

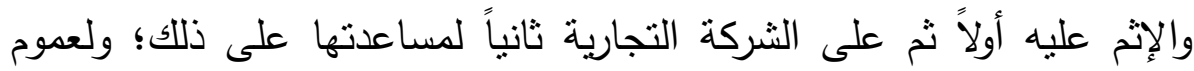

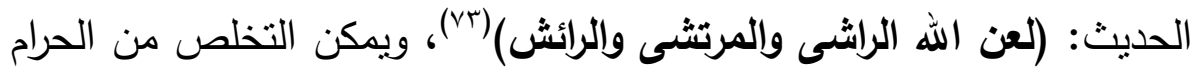

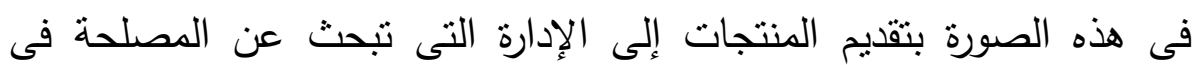

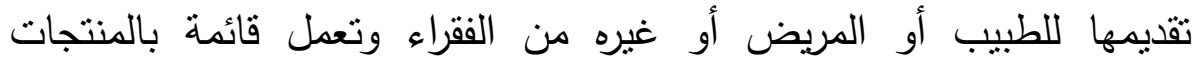

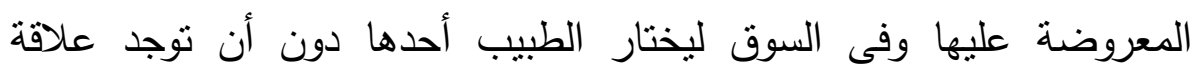

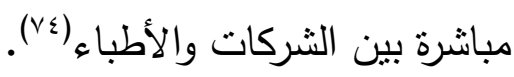


رابعا: لأن اختصاصه بالهدية وهو يعمل فى مكان لا يخصه يعد من باب الغلول لقوله عليه الصلاة والسلام: (هدايا العمال غلول) (Vo).

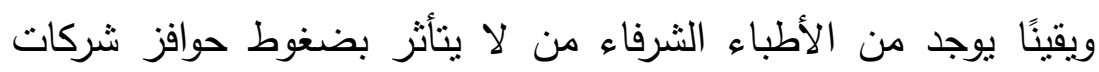

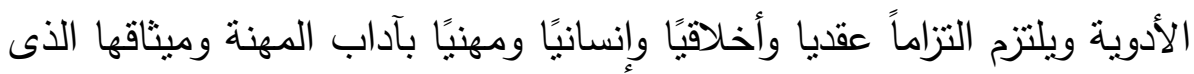

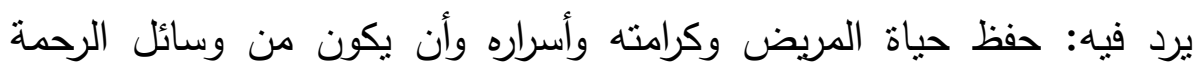

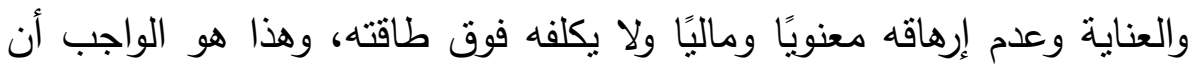
يكون (17)

فهؤلاء الأطباء يتعففون عن الحوافز التى تقدم لهم، وإن أخذت منهم على ونى

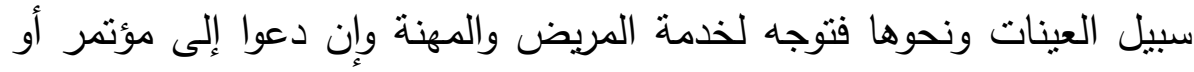
ندوة تكون نباتهم الصادقة والخالصة الاستفادة المهنية لإفادة المرضى.

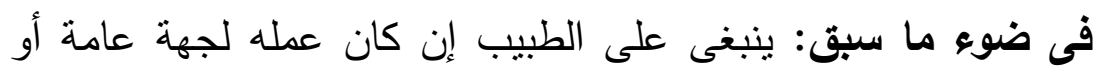
خاصة يتقاضى منها راتبًا نظير عمله أن لا يقبل هدية تتعلق بالعمل أو نأتيه

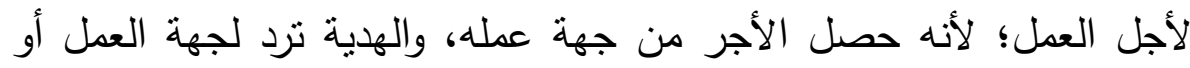
تبذل للفقراء.

ثم إن حدث وأخذ الطبيب هدية من شركة أدوية ووجهت لمصلحة

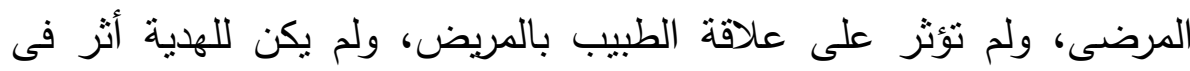

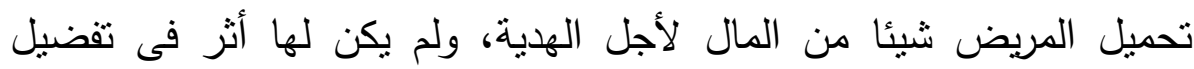

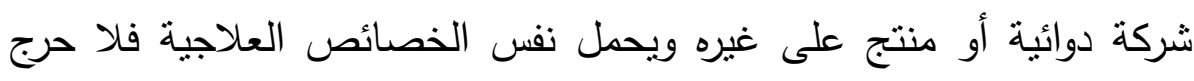
على الطبيب فى قبول تلك العينات المجانية، وذلك لما يأنى:

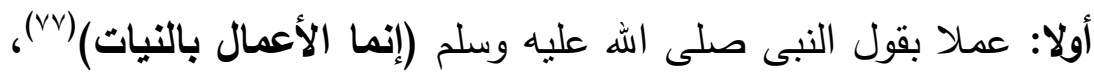
وقد تكون النية خالصة محضة فى إنفاق هذه العينات المجانية للعلاج وصرفها للمستحقين لها ولا اطلاع لأحد على نية غيره حتى يُحكم بتعميم الأمر . 
ثانيا: كما أنه لا يوجد أى مخالفة شرعية لاعوة الأطباء لحضور

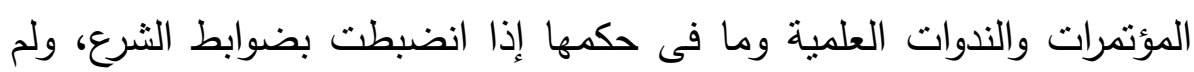
تكن فيها مجاملات لشركة على أخرى وكان ترتيب تللك الندوات والمؤتمرات

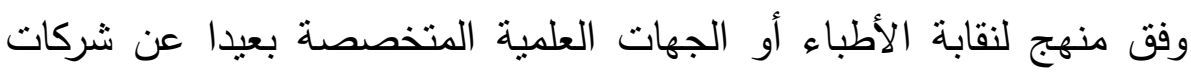

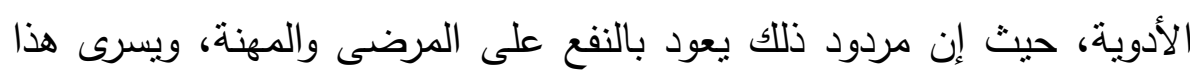

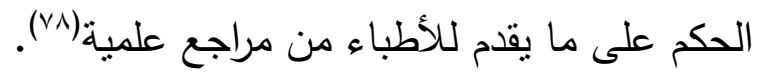

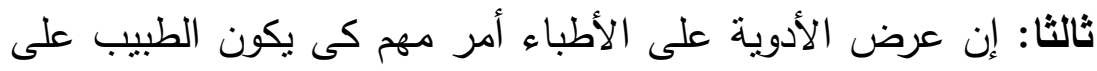

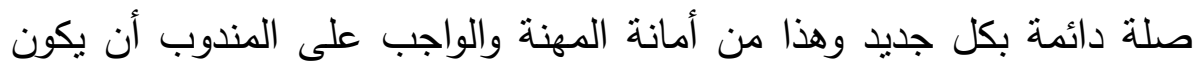

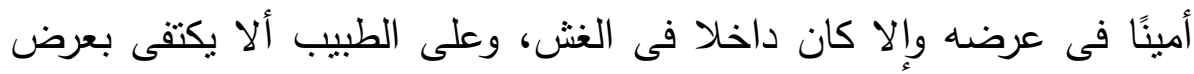

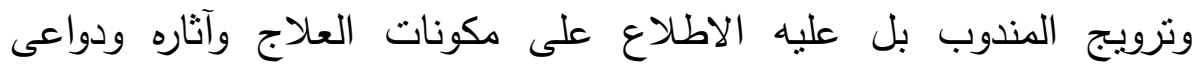
الاستعمال وموانعه ليقارن بين هذا المنتج وغيره وعليه أن يكون أمينًا فى حال صرف الدواء فالطبيب مستشار والمستشار مؤتمن.

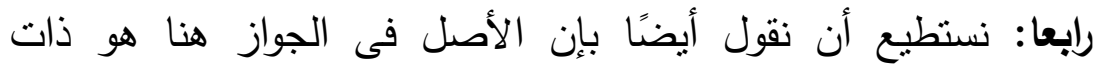
المريض ومدى استفادته منها، ولا أثر لهذه الهدية عليه مطلقًا من الناحية الهان

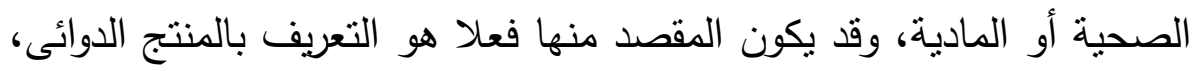
وتأخذ الهدايا المقدمة هنا حكم الهبة. يقول ابن قدامة رحمه الله: "ولا يصح تعليق الهبة بشرط؛ لأنها تمليك الهابك

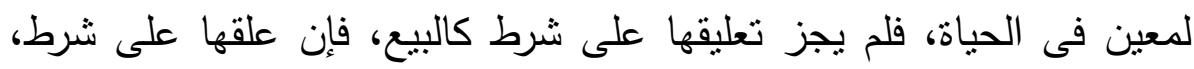

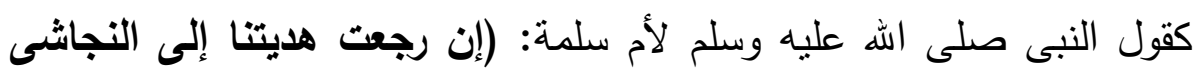

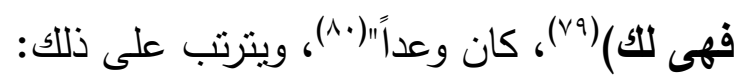
أولاً: جواز هذا النوع من الحوافز الترويجية إذا لم يكن لقبوله أثر على ولى الثى

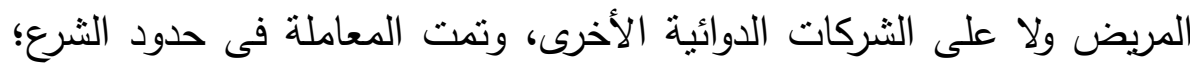


لأن الأصل فى المعاملات الحلّ، ما لم يقم مانع شرعى.

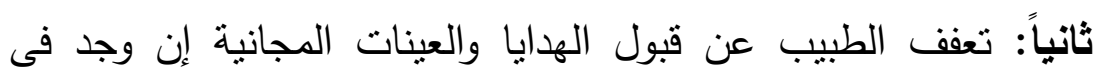

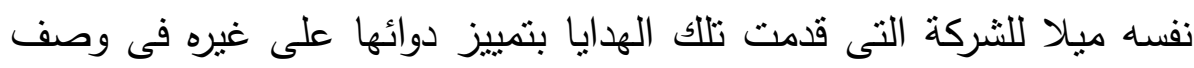

العلاج للمرضى، وفى الحديث: (الحلال بين والحرام بين وبينهما أمور

مشتبهات أو قال متثابهات لا يعلمهن كثير من الناس فمن اتقى الثبهات

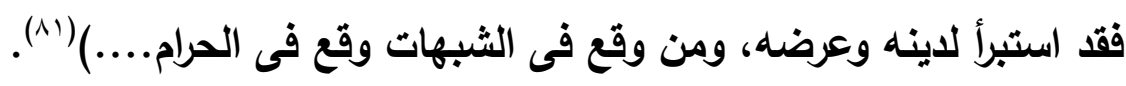

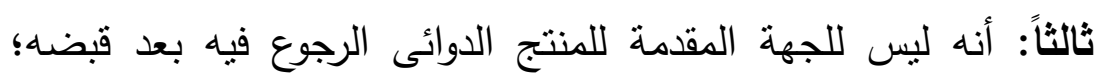

$$
\text { لعموم النهى عن الرجوع فى الهبة. }
$$

r - هدايا الأطباء لغرض ترويجى للسلعة، ولها أثر على المريض

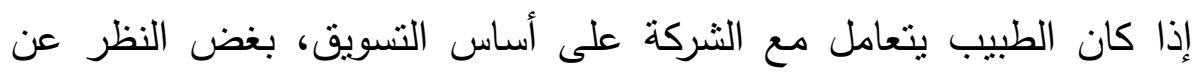

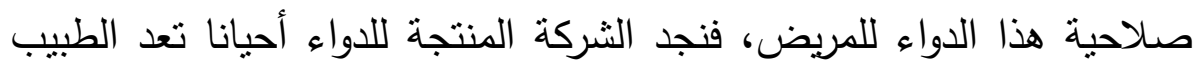

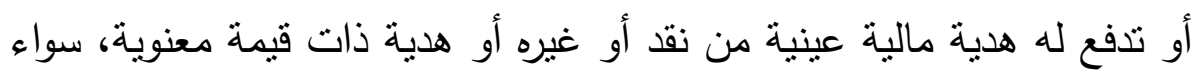

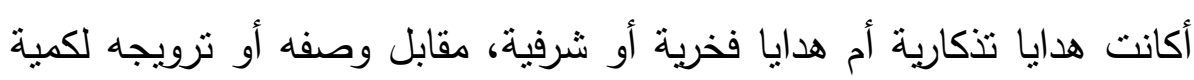

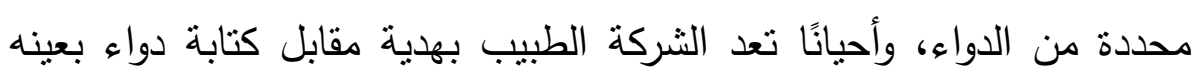
دون تحديد كمية، وقد تكون المادة الفعالة واحدة ولكن تتتج الدواء عدة شركات

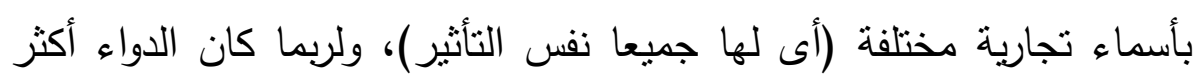

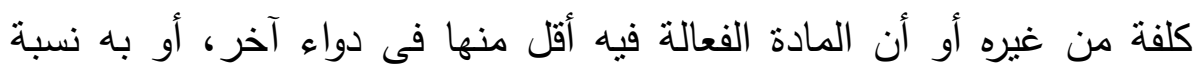

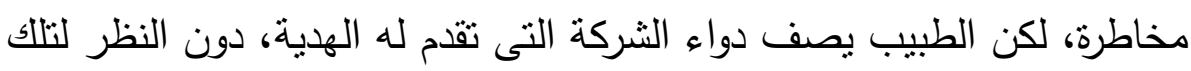
الاعتبارات.

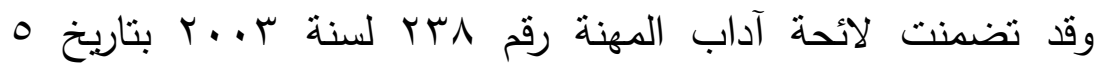

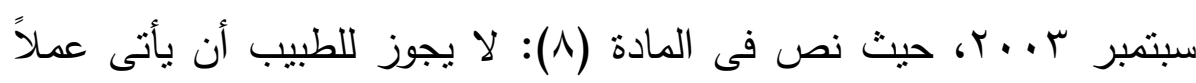
من الأعمال الآتية: 
أ - الاستعانة بالوسطاء فى مزاولة المهنة سواء كان ذلك بأجر أو بدون أجر .

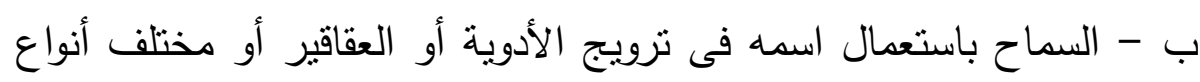
العلاج أو لأى أغراض تجارية على أى صورة من الصور . ج- طلب أو قبول مكافأة أو أجر من أى نوع كان الى نظير التعهد أو القيام

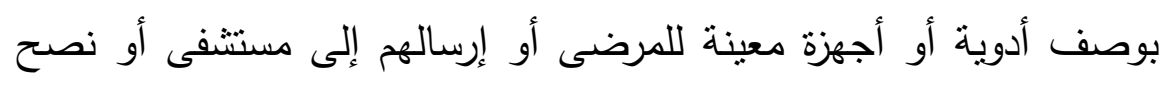

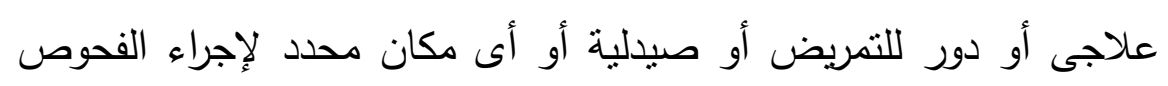
والتحاليل الطبية أو لبيع المستلزمات أو المعدات الطبية.

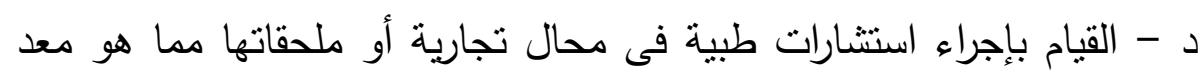

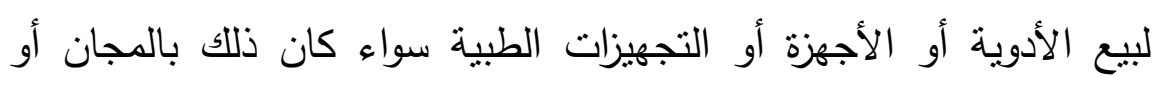
نظير مرتب أو مكافأة.

تعرض النظام التأديبى لنقابة الأطباء للجزاءات المترتبة على الترويج

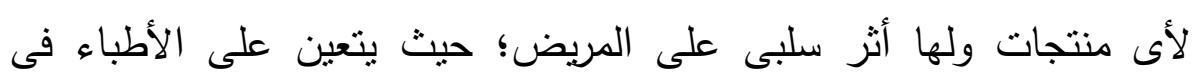

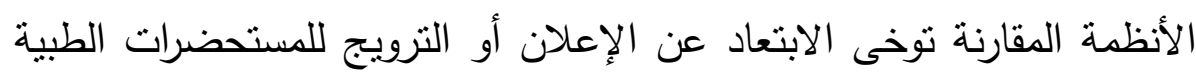

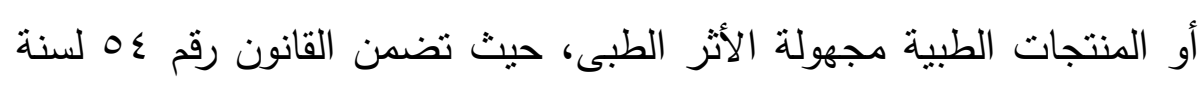

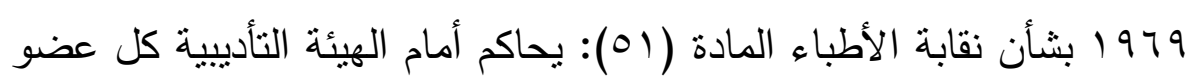

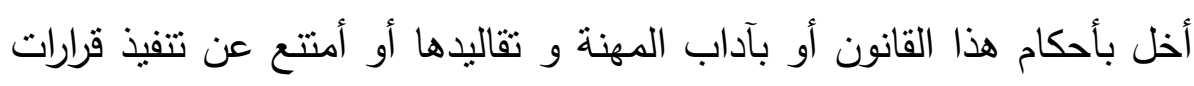

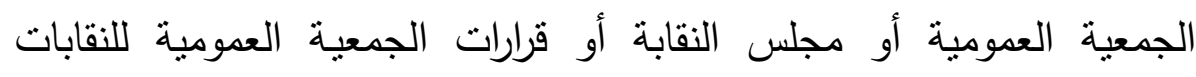

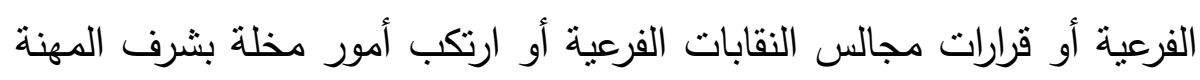
أو تحط من قدرها أو أهمل فى عمل يتصل بمهنته، كما نصت المادة (Y (O):

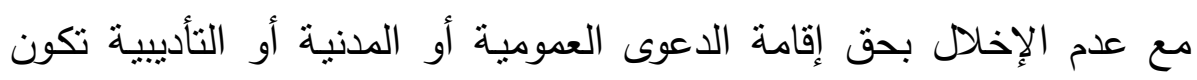

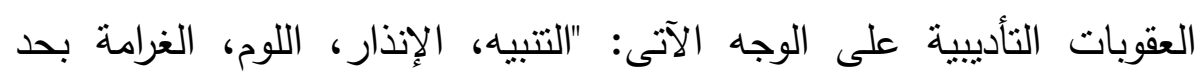

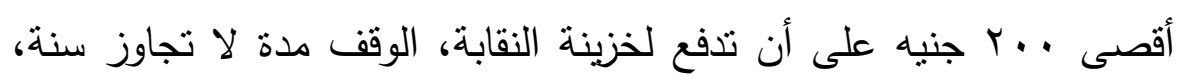


إسقاط العضوية من النقابة ويترتب على ذلك شطب الاسم من سجلات وزارة الصحة وفى هذه الحالة لا يكون للعضو الحق فى مزاولة المهنة إلا بعد إعادة قيد اسمه فى جداول النقابة".

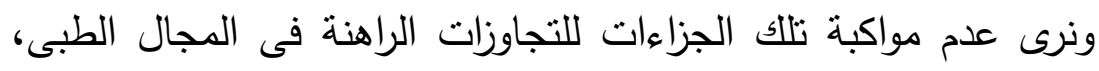

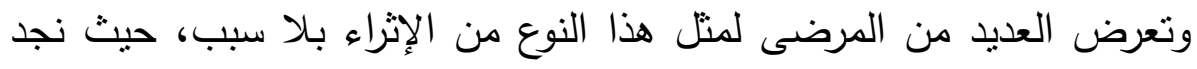

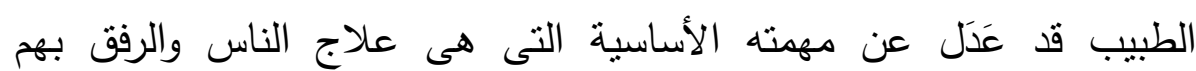

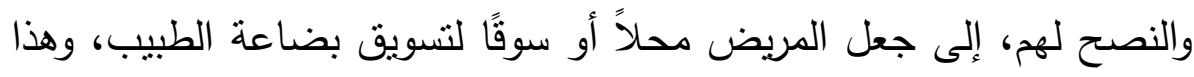
كله لا شك غش للمريض، وقد نهى الإسلام عن الغش، فقال صلى الله عليه وسلم: (من غشنا فليس منا) (Ar).

وهذه الهدايا المقدمة لهذا الغرض نأخذ حكم التحريم بذلاً وقبولاً؛ لأنها

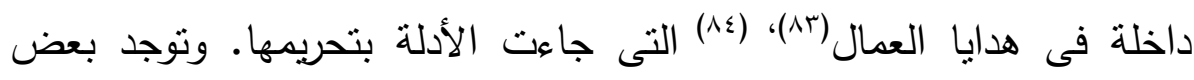

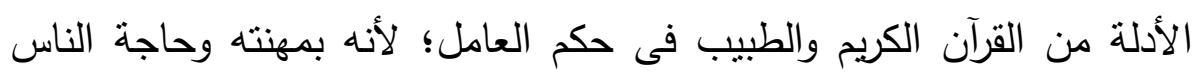

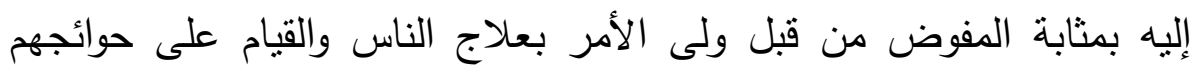
العلاجية. (10).

فهذه النصوص تدل على تحريم قبول الأطباء الهايا التى تمنح لهم بسبب عملهم نظير ترويجه لأدوية تلك الثركات مع زيادة سعرها عن غيرها

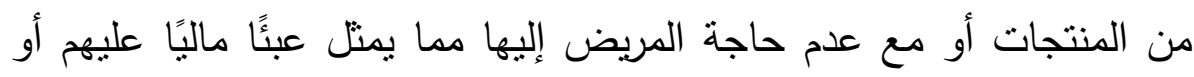

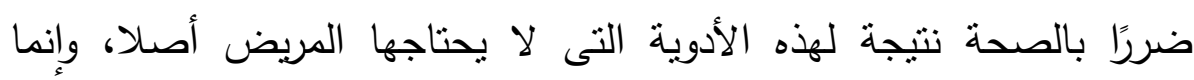

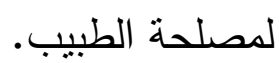
وأما من المعقول: فلأن المريض حينما يذهب إلى الطبيب فإنه يضع فيه

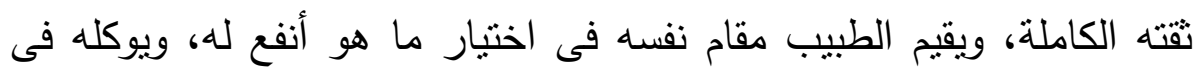
ترشيح دواء مناسب له، ولا يدور بخلده أبدًا أن هذا الطبيب بمكن أن الن يخونه 
وإلا لما ذهب إليه، وأسلم إليه نفسه ومكنه منها، فأصبح الطبيب وكيلا عن المريض فى مداواته، واختيار ما ينفعه، ويصلحه، فإذا اختار له شيئا وهو يعلم

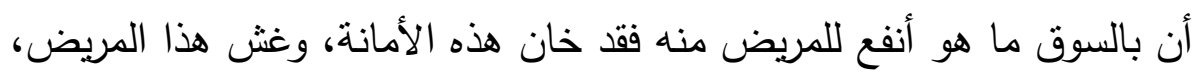

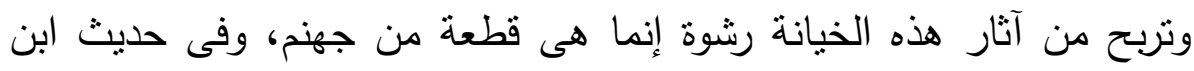

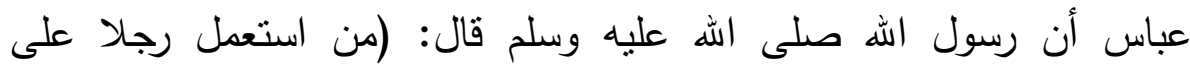
عصابة، وفى تلك العصابة من هو أرضى الله منه؛ فقد خان الهه ورسوله، وخان النه جماعة المسلمين) (†').

والحديث السابق وإن كان ضعيفًا، إلا أنه لا ينفى أن ذلك واجب فى في

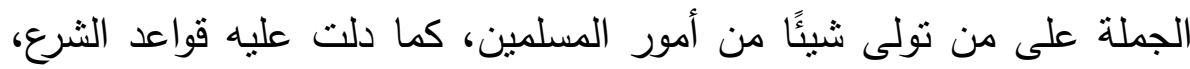

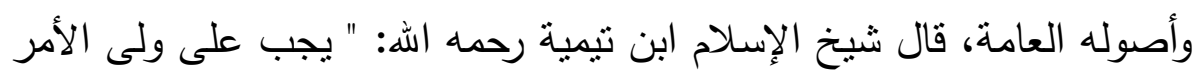

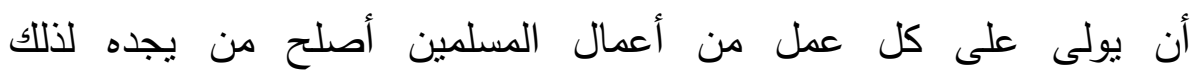

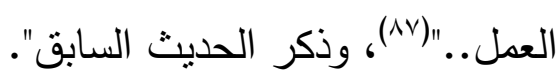

وأيضا: فإن الطبيب إذا فعل ذللك فإنما يكون قد فرط فى فريضة إسلامية

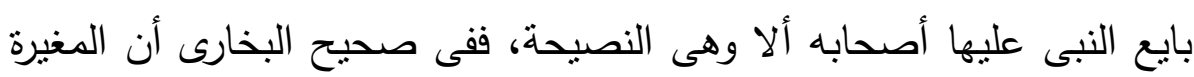

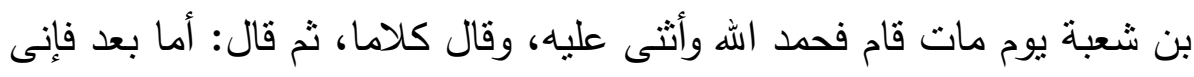

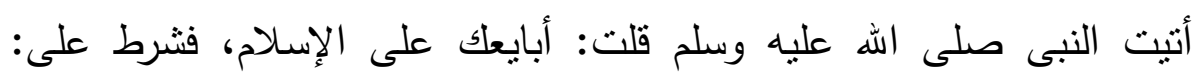

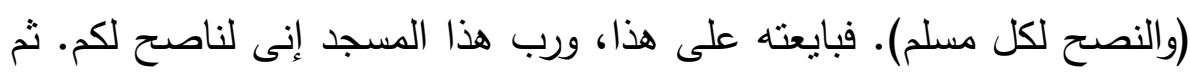

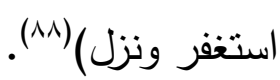

وعلى ذللك فمتى رغب الطبيب عن اختيار أكفأ الأدوية وأرخصها إلى ما هو أنفع له هو فإنه يكون آثنا للأسباب النالية:

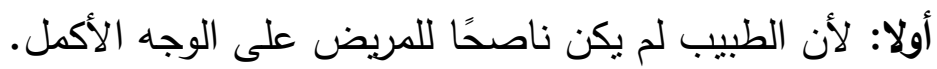

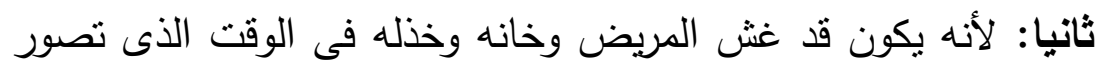


المريض فيه أنه ناصر ومعين له.

ثالثا: الطبيب بمثابة الوكيل عن المريض فئ اهئ اختبار أكفأ الأدوية وأقلها كلفة، وبفعله هذا يكون قد فرط فى عقد الوكالة، وأهدر أهم قيمها وهى الأمانة. رابعا: لو فتحنا للطبيب باب التربح من هذه الهدايا لتنافست الثركات فى لهى اجتذاب الأطباء من هذا الباب بدلا من تحسين أدويتهم، ولصار للطبيب مستتد فى حل هذا الفعل، فيجد المريض نفسه فريسة بين شركة كل همها التسويق، وبين طبيب كل همه الحصول على الهدية.

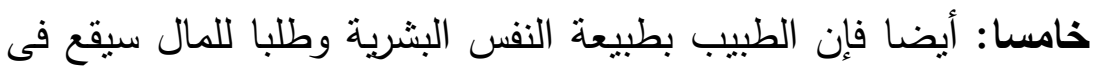
حيرة، بين أمرين، أحدهما مراعاة حال المريض فيبحث عن أفضل الأدوية الفية

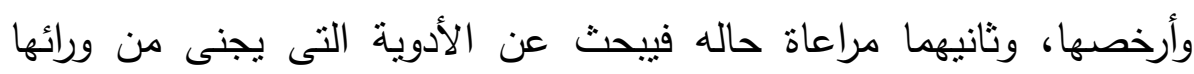

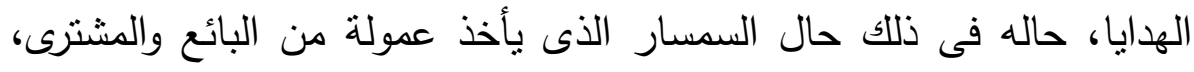

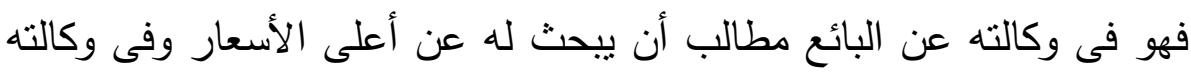

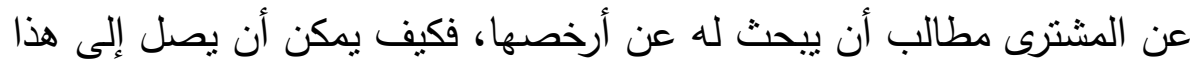

$$
\text { وذالك فى وقت واحد. }
$$

ولم تحدد التشريعات المعاصرة، كافة صور الخطأ الطبى بشكل دقيق ومنها وصف أدوية قد يكون لها تأثنر سلبى، فهذا الأمر يكاد يكون أقرب إلى لى لئل

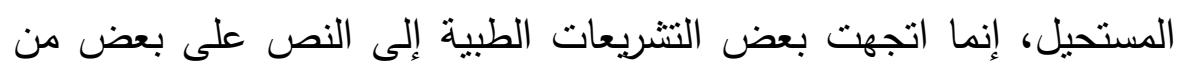
صور الأخطاء الطبية(^9). - المعيار المعُول عليه كمقياس للخطأ الطبى الني عرضنا آنفا صور الخطأ الطبى ومنها وصف دولئه تحقق الضرر بصفة فعلية- ، كأساس المسئولية الطبية، وانتهينا إلى أن مفهوم الخطأ الطبى لدى أغلب التشريعات التى تقرر المسئولية، هو ذلك الخطأ الذى لـى 
يرجع إلى الجهل بأمور فنية(·9) يفترض فى كل من يمارس المهنة الإلمام بها أو كان هذا الخطأ راجعاً إلى الإهمال أو عدم بذل العثل العناية اللازمة، ولكن تبدو

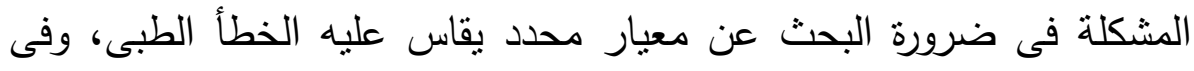
هذا الصدد، تنعفنا الاتجاهات المختلفة بأن هناك ثمة معيارين على النحو التالى :

1 - معيار الخطأ العادى: معيار الخطأ العادى هو ما يرتكبه الطبيب

عند مزاولته لمهنته دون أن يكون لهذا الخطأ علاقة بالأصول الفنية لرهنة الطب(19)، بمعنى أن ارتكاب المخالفة تدخل ضمن العناصر المعروفة للخطأ

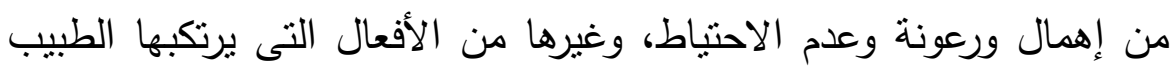

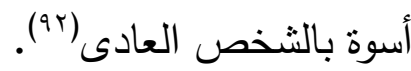

r - معيار الخطأ المهنى: يرتبط هذا المعيار بالقواعد العلمية والأصول

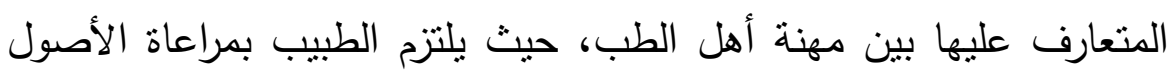

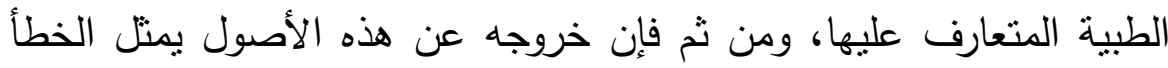

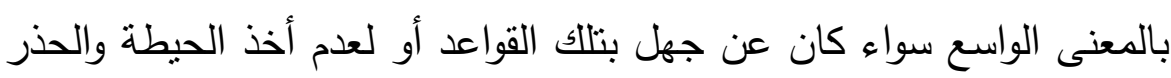

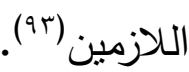
ولكن هناك ثمة اختلاف بين الفقه، فى تحديد درجة الخطأ المطلوب

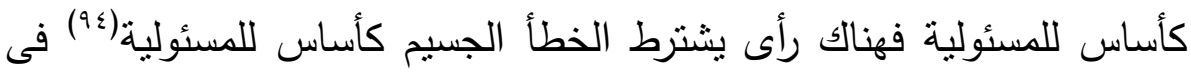

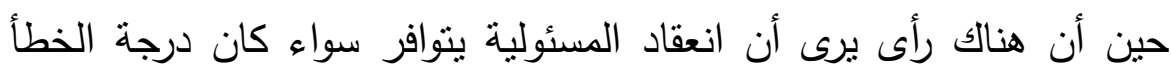

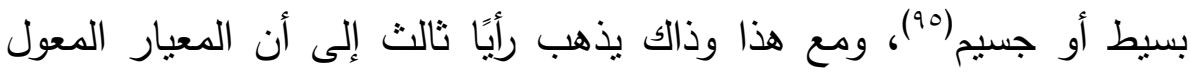

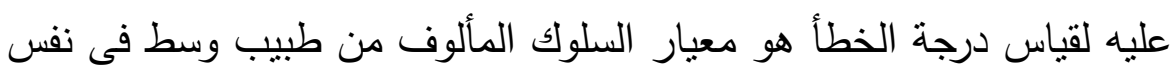

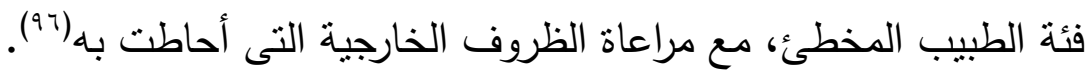


يبدو أن ضرورة البحث عن معيار ملائم لتحديد الخطأ فى مجال

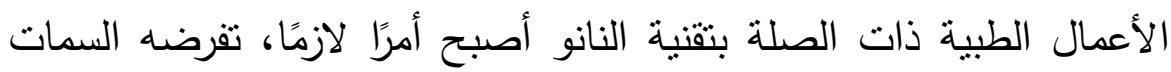

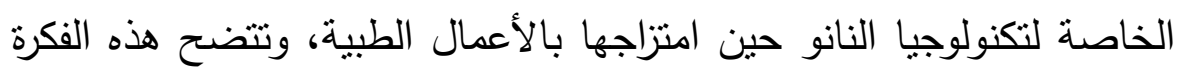
بصفة خاصة، حين يفرض الواقع العلى، صعوبة تحديد المنسبب فى الخطأ

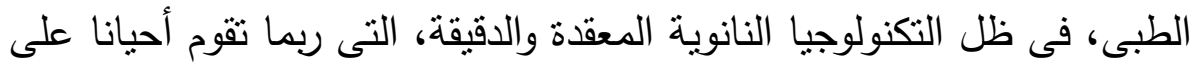

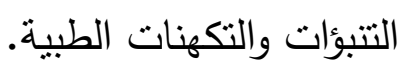

مثال ذلك، صعوبة تحديد السؤلية الجنائية عن الأضرار التى تصيب

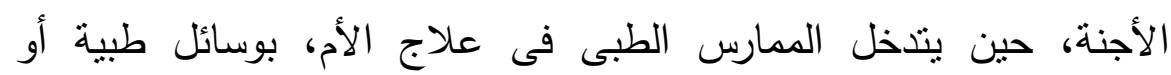

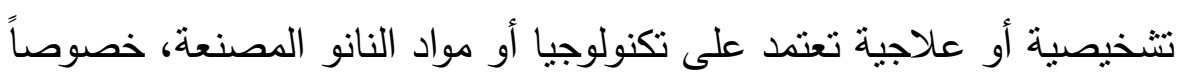

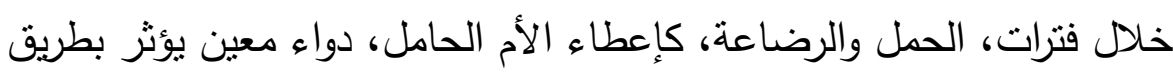

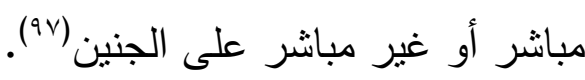

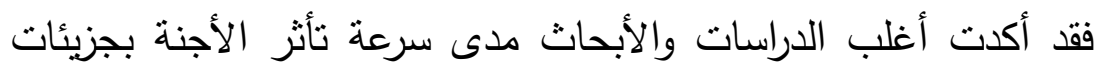

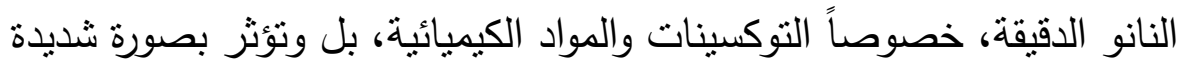

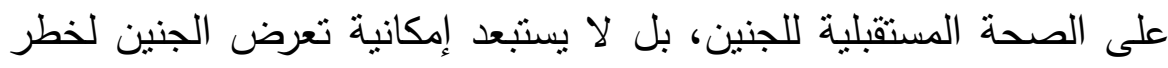

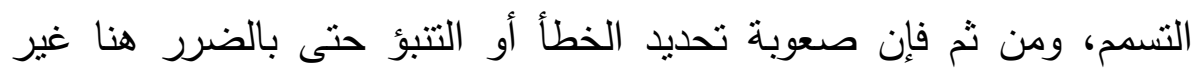
واضح نظراً لحداثة هذه التقنية.

\section{ثالثا: العمولات المادية التى يمصلها الطبيب هن هندوبى شركات}

الأدوبة)(9^)

تعد مهنة الطب من المهن الاجتماعية المهمة، وهى من أرقى المهن، كيف لا لإداهل

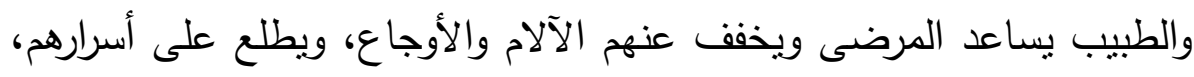

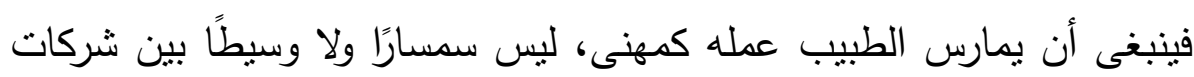


الأدوية وبين المرضى، وليس تاجرًا كل همه تحصيل المال، وأيما طبيب أتجر على حساب مرضاه ولم ينصح لهم كان غانثًا ظالئًا.

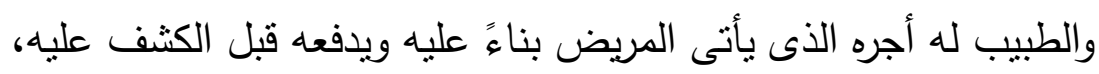

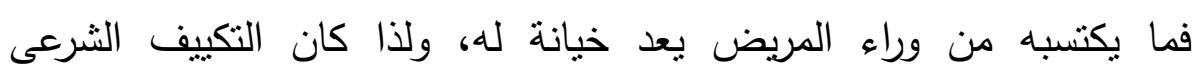

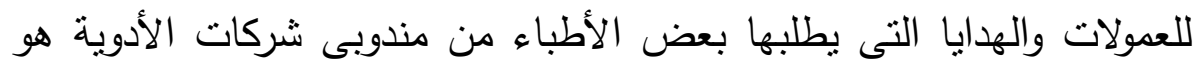

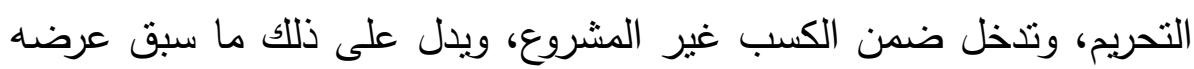

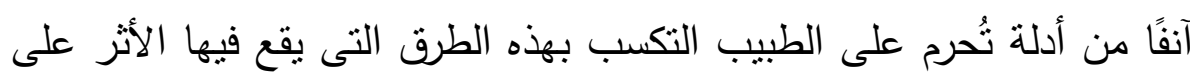

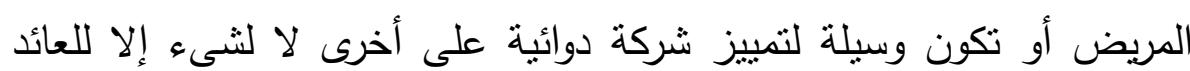

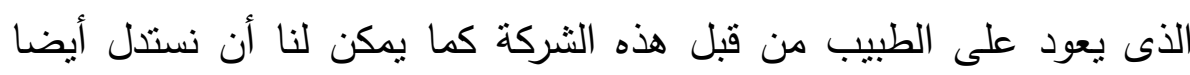

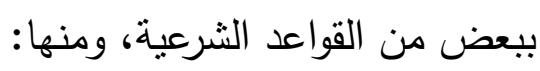

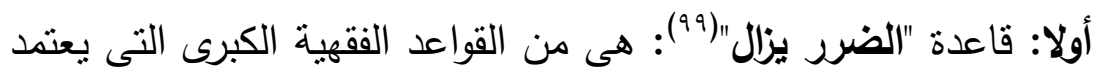

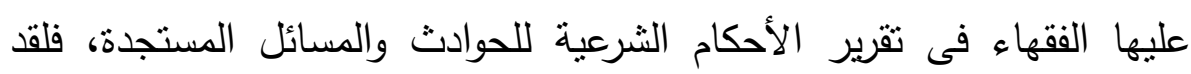

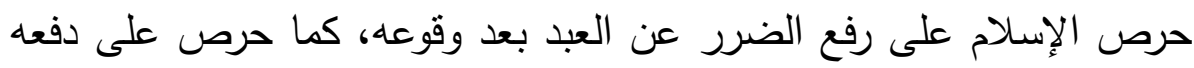

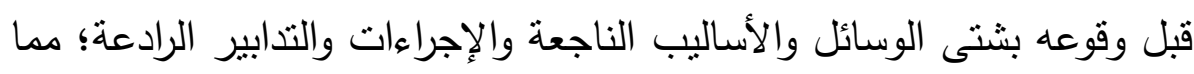

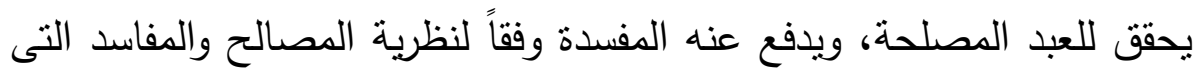
تقتضيها المقاصد الثرعية لحفظ نفس العبد ودينه وعرضه وعقله وماله. ولا شك أن ضررا هنا يقع على المريض بالاستفادة المادية التى تعود

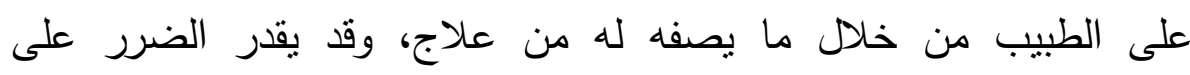
الثركات العلاجية المنافسة كنلك، والضرر يزال.

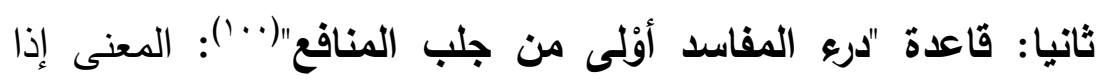

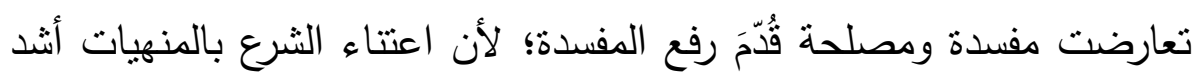

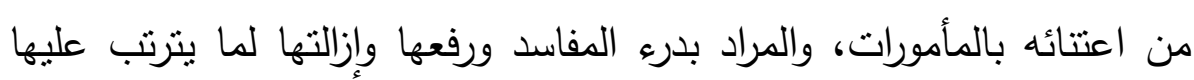


من ضرر ينافى حكمة الشرع فى النهى، فإذا أراد شخص مزاولة عمل ينتج له منفعة أو ربحًا، ولكنه من الجهة الأخرى يستلزم ضردًا يلحق بالآخرين مساويًا

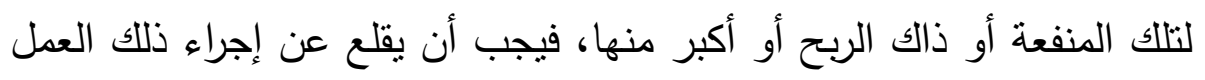
دريًا للمفسدة المقدم دفعها على جلب المنفعة. ومنفعة الطبيب هنا تتعارض مع مصالح المرضى، أو يترتب عليها مفاسد تلحق بالمرضى والثركات العلاجية المنافسة، فيقام دفع المفسدة هنا على جلب المصلحة. ثالثا: قاعدة وسائل الحرام حرام: يقصد بهذه القاعدة أن تكون الغاية من المعاملات المالية مشروعة ومتفقة مع أحكام ومبادئ الثريعة الإسلامية،

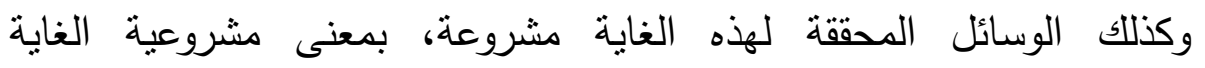

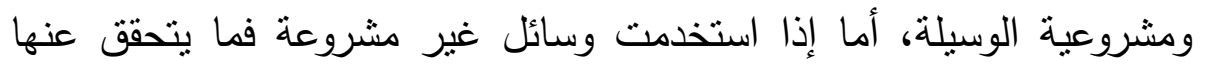

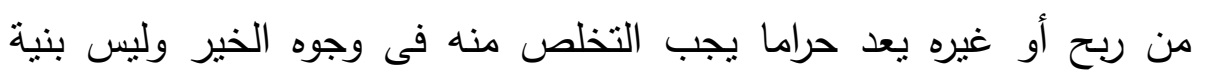

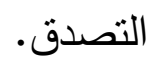

فعلى سبيل المثال يعتبر المال المتحصل عليه من الربا والغش والرشوة

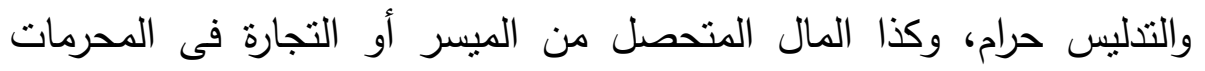

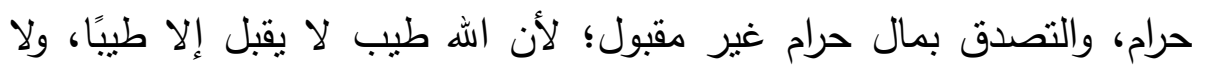
تقبل صدقة من غلول(1 (1). ويشترك فى الإثم مندوب شركات الأدوية الذى يساهم فى إفساد الذمم

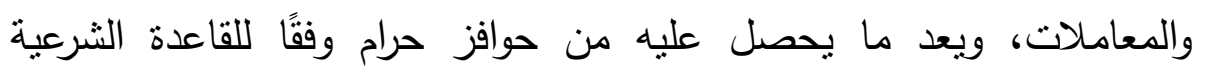
المذكورة بعاليه: "وسائل الحرام حرام" ولقد أكد الفقهاء على أمر مهر ولى وهو : مشروعية الغاية ومشروعية الوسيلة". 
رابعا: قاعدة إذا اجتمع الحلال وإلحرام غلب الحرام(ץ + 1): معناها أن كل أمرٍ

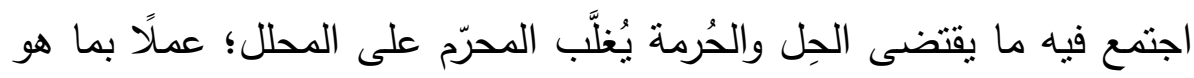

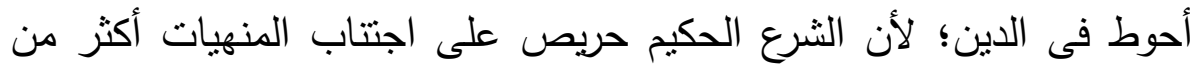

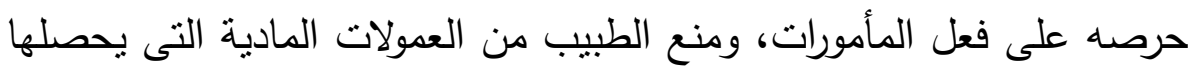
من شركات الأدوية أو مندوبيها يغلب فيها الحظر على الإباحة.

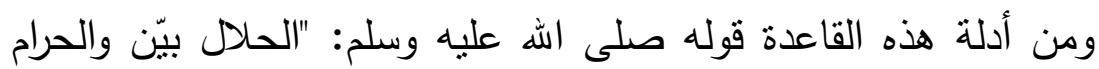

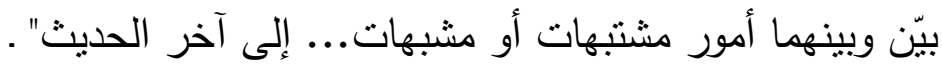
1- ضابط جواز الهدايا للطبيب

ذكرت فيما سبق فى حكم الهدية إن كان لها أثز على المريض أو لم يكن لها أثز، وكذا بإن كان لها أثر على الثركات المنتجة المنافسة، وبينت أقوال

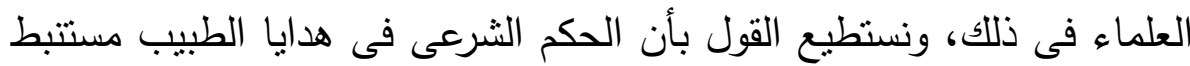
من حكم الهدية للقاضى وهدايا العمال؛ وعمل الطبيب من حيث الحاجة

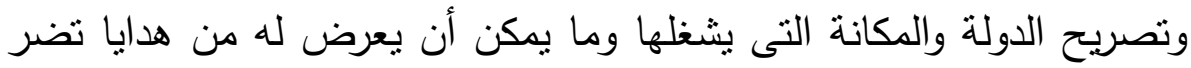

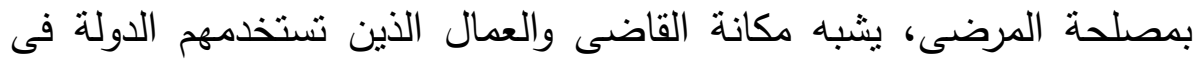

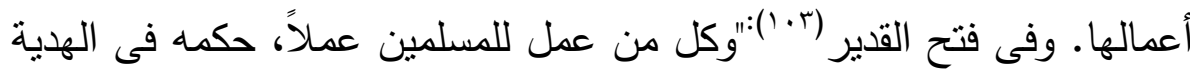

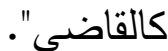
ويمكن أن نقول: "جواز الهدايا للطبيب بأنواعها سواء الأعيان أو المنافع

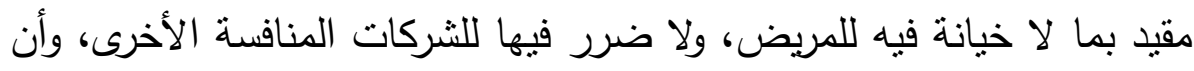
لا تكون الهدية مظنة تهمة وريبة". هذا الضابط مستتد إلى الغاية والعلة التى من أجلها منعت الثريعة هدايا

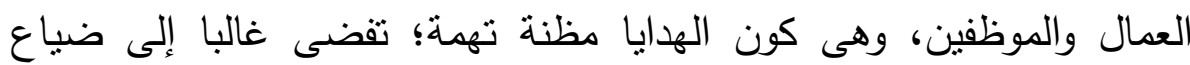

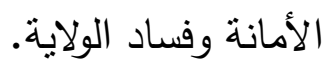


قال ابن حجر الهيتمى: "الهايا منى لم يقصد بها معنى الرشوة ولا

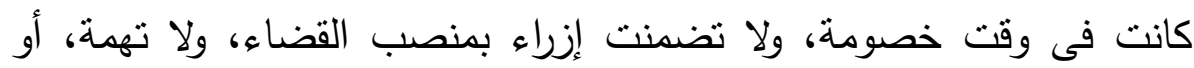

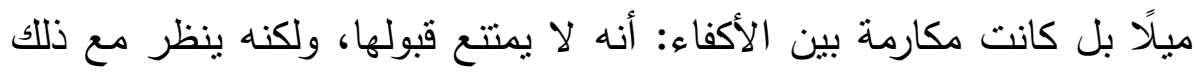
إلى المعنى الباعث لصاحبها على الإهداء"(\& +1). ولهذا المعنى نص جماعة من الفقهاء على منع الحاكم والقاضى من الإهاء

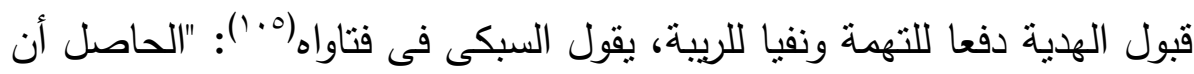

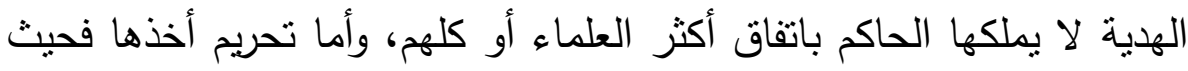
أوجبت ريبة حرم عليه قبولها".

ب - إحالة الطبيب المرضى إلى مختبرات محددة قد يجرى اتفاق بين الطبيب وبين الجهات التى يحتاج المريض إجراء

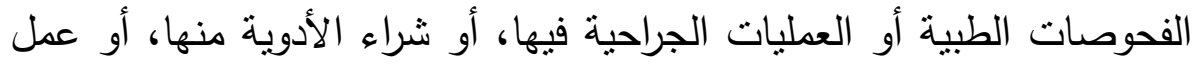

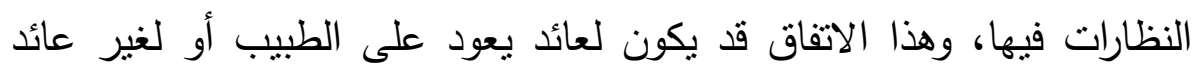

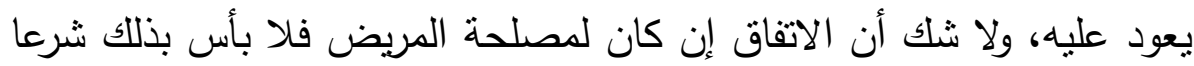
وهى تلحق بالمبحث السابق حكما ودلالة. وأما إن كان تحويل المريض على تللك الجهات لعائد يعود على الطبيب لتحصيل نسبة مادية متفق عليها بينهم، فلا شك أن هذا الأمر محرم

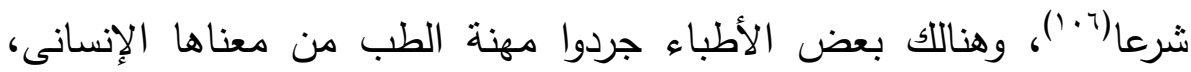

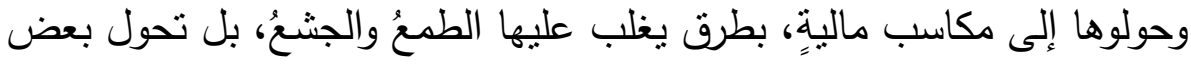
الأطباء إلى سماسرة لبعض شركات الأدوية، لتسويق أدويتها مقابل نسبةٍ معينةٍ

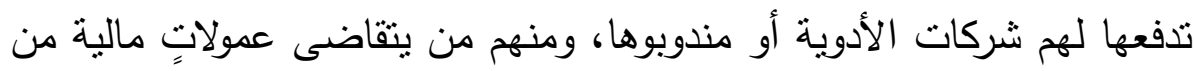
بعض أصحاب المختبرات الطبية لتحويل المرضى إلى تلك المختبرات وزيادة

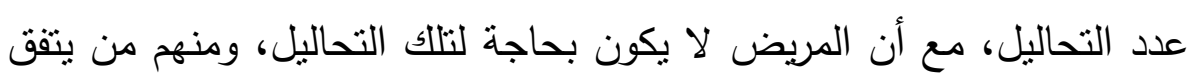


مع بعض الصيادلة لتحويل المرضى إلى صيدلياتهم ووصف أدويةٍ كثيرةٍ لا

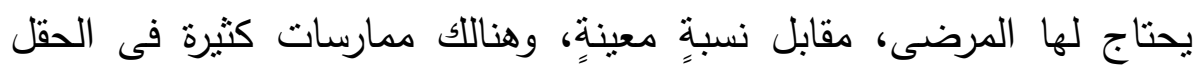
الطبى يكون الهذف منها استغلال المريض واستنزافه مالياً، وهذه الأعمال وأمثالها جعلت بعض الأطباء تجاراً وسماسرة على حساب المرضى.

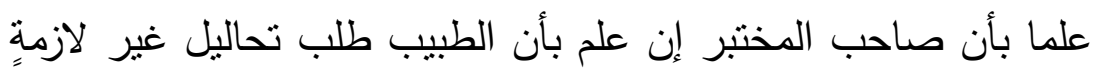

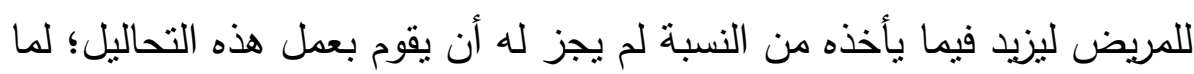

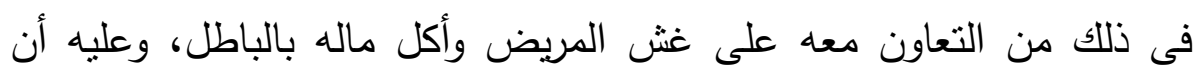
ينصح للطبيب عسى أن يتوب عن ذلك، وتشلم الأطراف الثلاثة، أما إذا لم الم يعلم صاحب المختبر بذلك فلا إثم عليه فى القيام بنالك النحاليل".

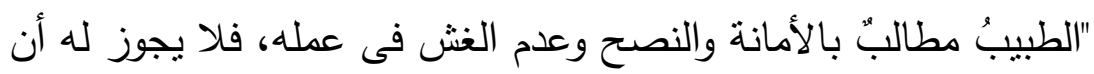

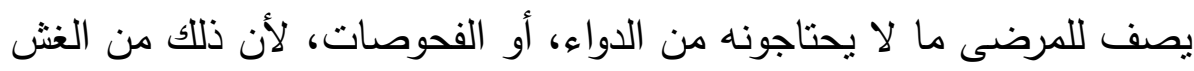

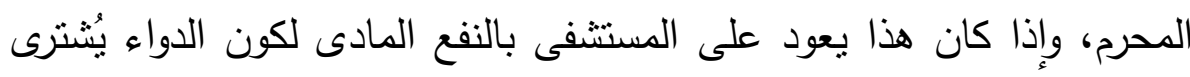

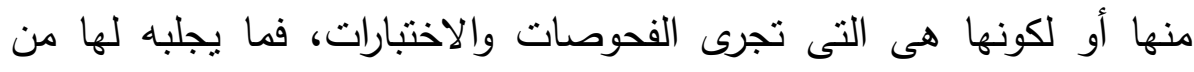

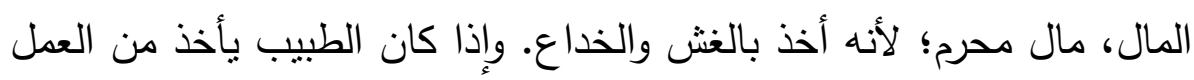

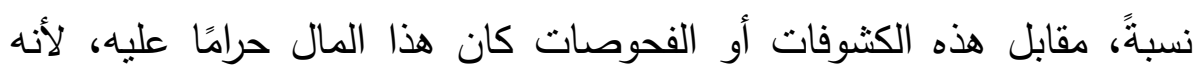

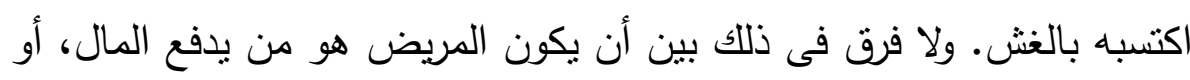

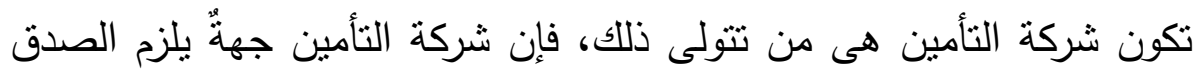

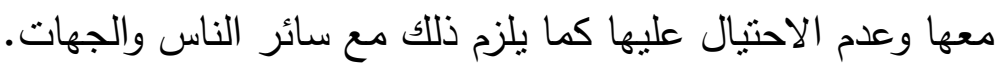

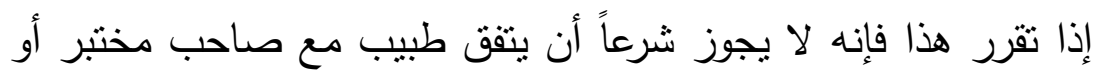

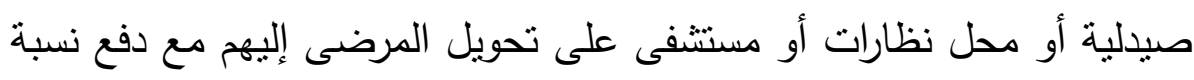

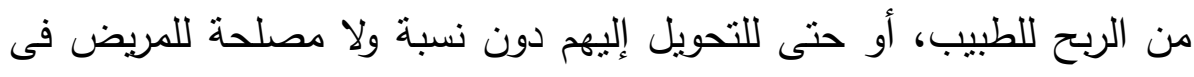


تحديد هذه الأماكن، وما يأخذه الطبيب من أموالٍ فى هذه الحال يعتبر من أكل

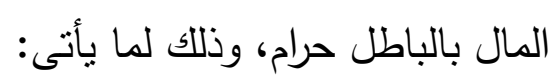

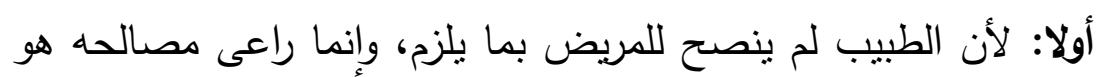

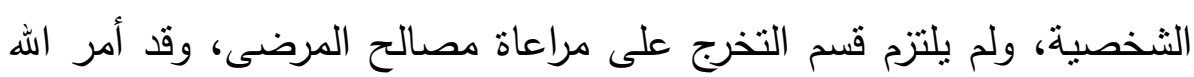

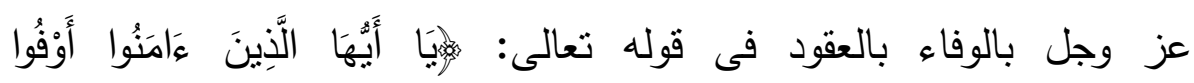

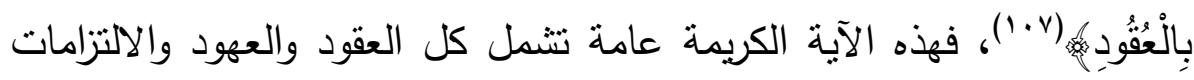
التى يلتزم بها الثخص مع غيره.

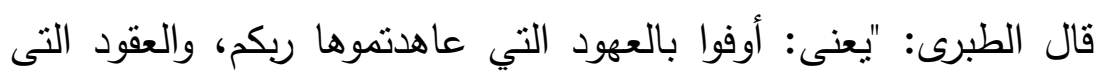

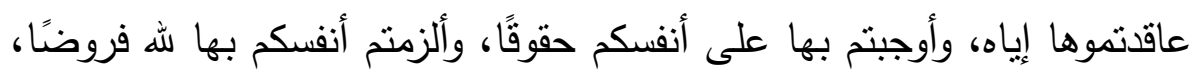

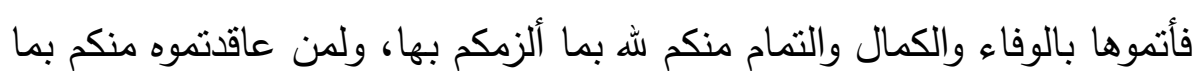

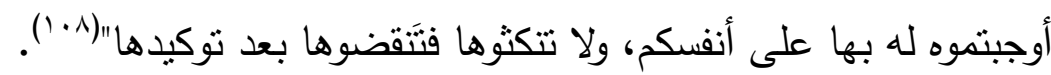
ثانيا: أيضا لما فى ذلك من المفاسد المترتبة على ذلك بناءً على لفى قاعدة:

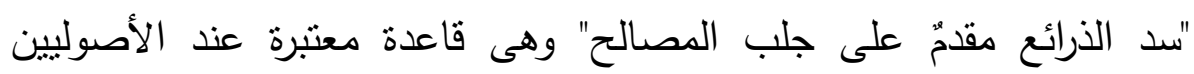

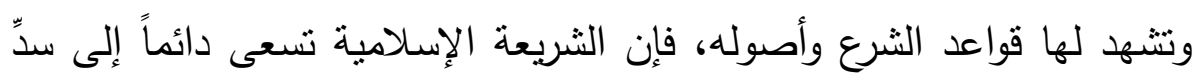

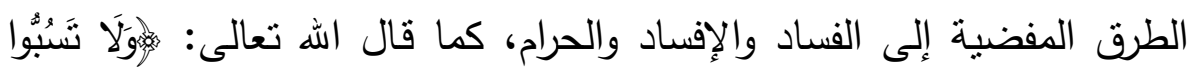

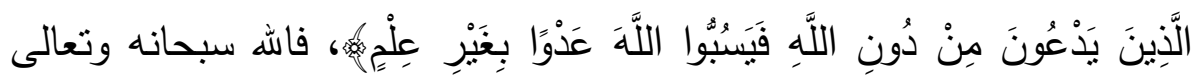

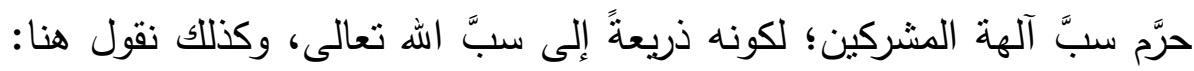

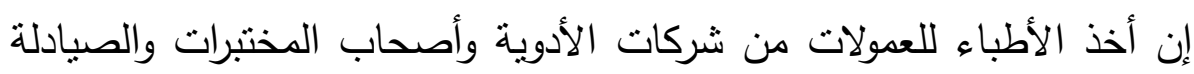

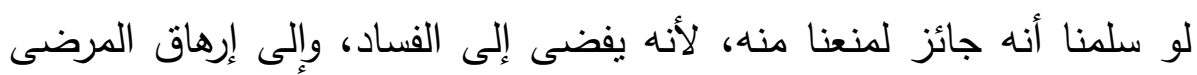

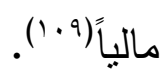

ثالثا: يحرم هذا الأمر أيضًا استتادًا إلى قاعدة: "لا ضرر ولا ضرار"

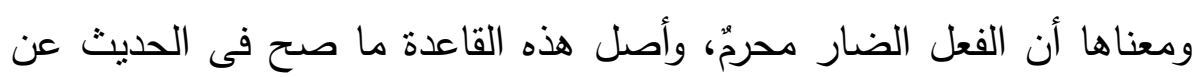


ابن عباس رضى الله عنهما أن الرسول صلى الله عليه وسلم قال: [لا ضرر ولا

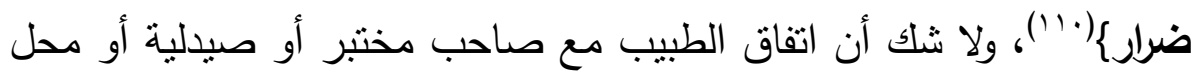

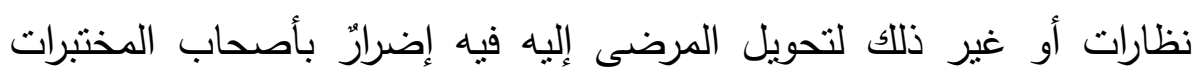

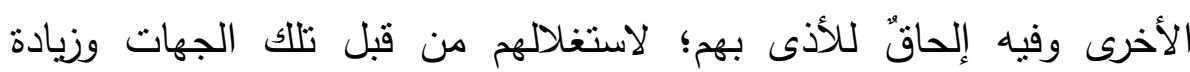

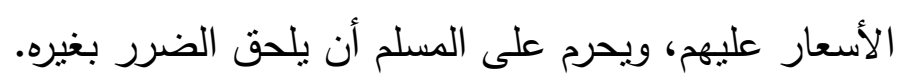

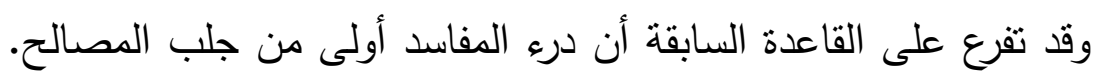

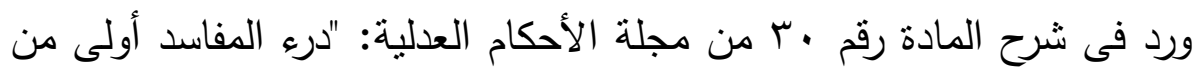

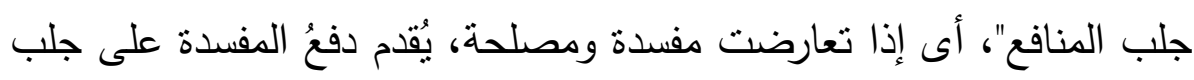

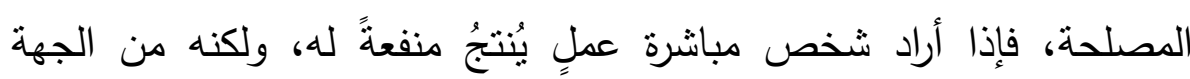

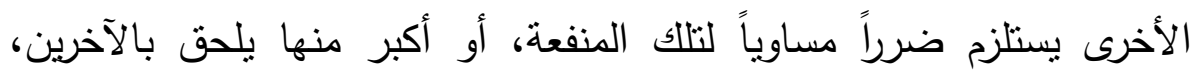

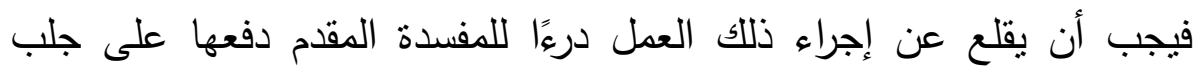

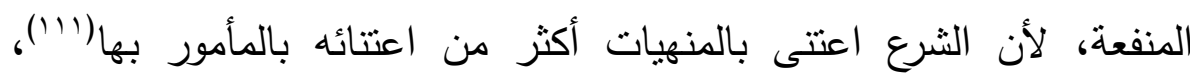

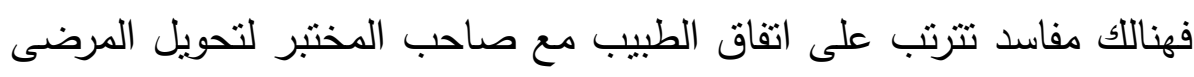

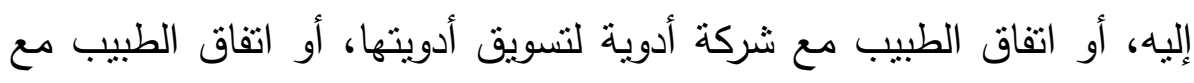

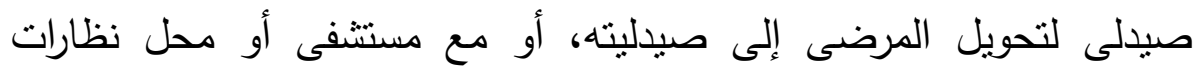
لتحويل المرضى إليهم، وكل ذلك مقابل عمولةِ مالية.

لا شك أن من السبل المستحدثة للمنافسة غير المشروعة والاحتكار بصفة عامة، وفى المجال الطبى بصفة خاصة، يتمتل ذللك فى استخدام الإعلان كوسيلة للتضليل، وقد تصدى التنظيم العربى لتلك الأساليب غير المشروعة

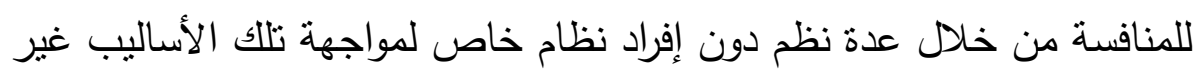


المشروعة للمنافسة ووسائل تضليل المستهلك، ولم تعالج القوانين الإعلانات

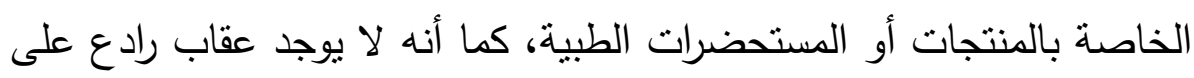

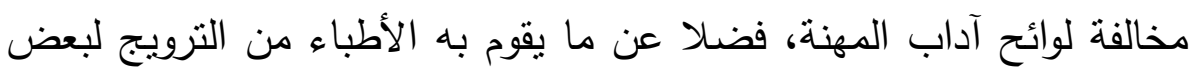

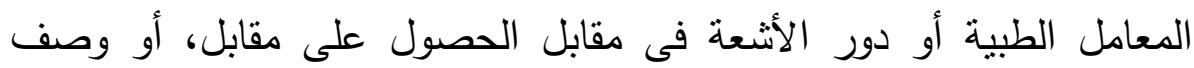
وصفات طبية لبعض أصناف الأدوية والتى مبناها تحقيق نسبة من المبيعات، أو مقابل تغطية شركات الأدوية لنفقات المؤتمرات، وكذلك السفريات الخاصة لاصنة

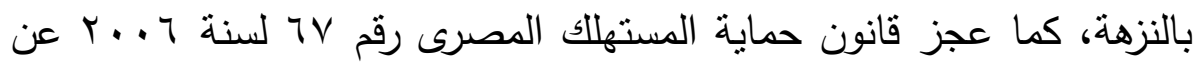

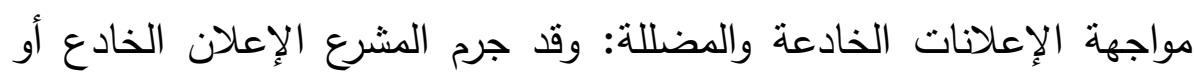

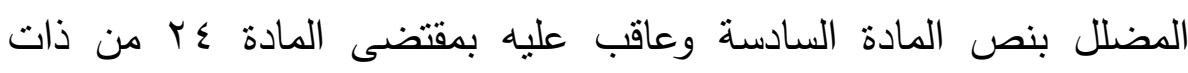
القانون، وأن كان من الملاحظ على هذا التتاول التشريعى لجريمة الإعلان

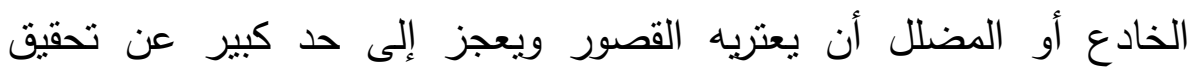
مقاصده لعدة أسباب نجملها فيما يلى: 1- ربط الإعلانات الطبية فى وسائل الإعلام بمنظومة رقمية تبين بلد المنشأ

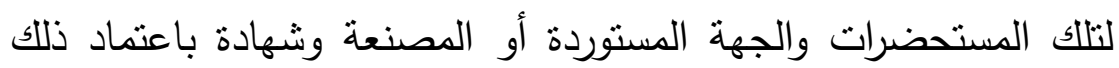
الدواء من وزارة الصحة، وكذلك ربط الوصفات الطبية للصيدليات والمعامل وكافة المنشآت المرتبطة بالعمل الطبى بمنظومة إلكترونية

$$
\text { تخضع جميع المعاملات الطبية لسجلات رقمية. }
$$

r- عمل دليل لآليات العمل الطبى فى مجال التشخيص والعلاج وأن ينم إفراد

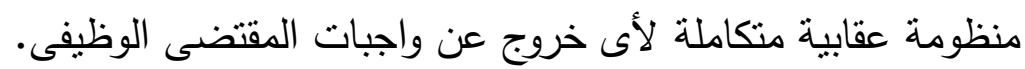

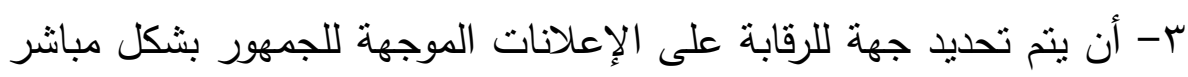

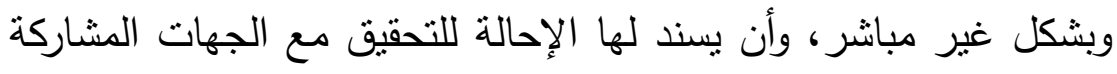
للترويج للإعلانات الخادعة وأن تملك إنشاء صندوق لمواجهة الإعلانات 
الخادعة، ومقاضاة الجهات والأجهزة المشاركة فى الإعلانات الخادعة.

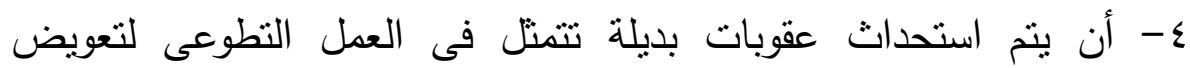
المخاطر المحتملة عن الترويج المضلل. 0- تثديد قيمة الغرامات المالية لتصل لحد مصادرة المكسب المتحصل من الترل

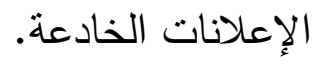
צ- قصر نص المادة السادة الحماية المقرة من الإعلانات الخادعة على الإعلى

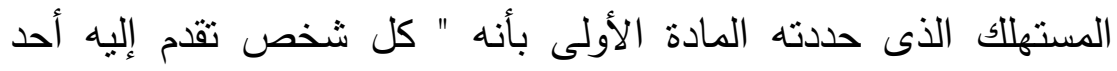

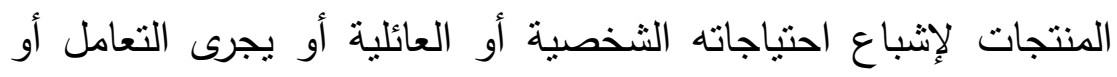

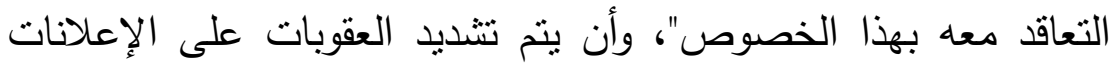

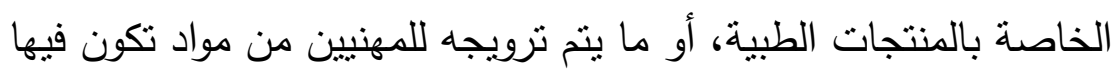
تحايل على المبين فى دليل الإرشاد الخاص بالمنتج. V - كما أنه قصر صفة المستهلك حال التعاقد على المنتجات دون الخدمات

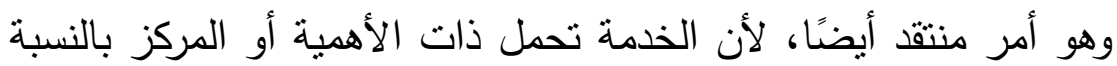

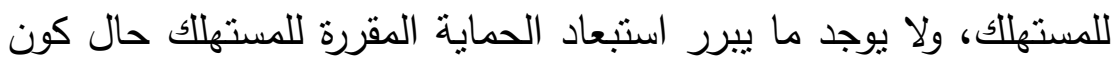
محل الخداع خدمة. 1- ويؤكد هذا التوجه من قبل المشرع حال نصه فى المادة السادسة على إلزام كل من المعلن والمورد بإمداد المستهلك بالمعلومات الصحيحة عن طبيعة

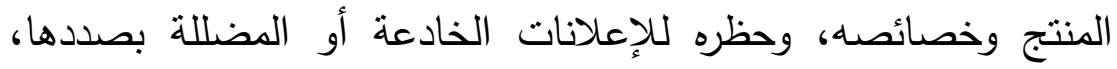

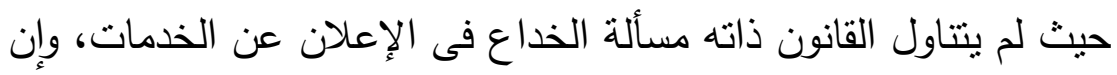

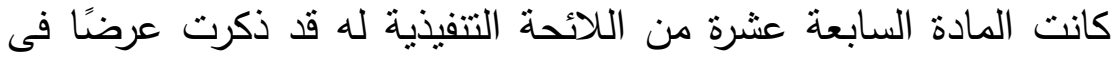

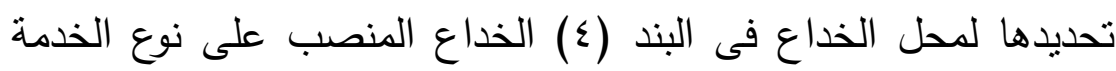

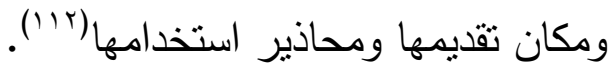


9- أن المشرع قد حدد معالم هذه الجريمة وبين مفردات الوصف القانونى أو النموذج الإجرامى المكون لها فى نص واحد، وهو ما يمثل اجحافاً كبيراً

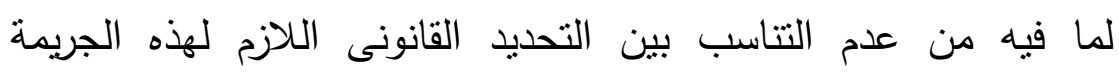

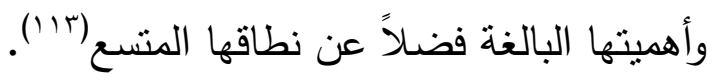
• 1- لم يكن المنظم المصرى دقيقًا فى بيانه وتحديده لأركان جريمة الإعلان البهان

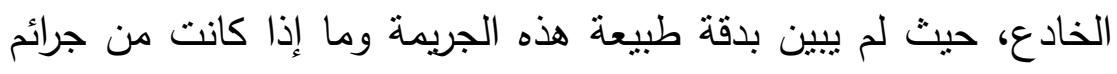

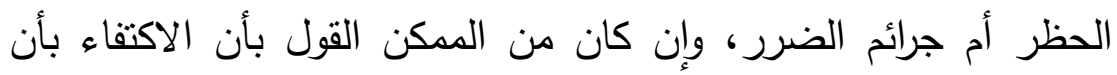

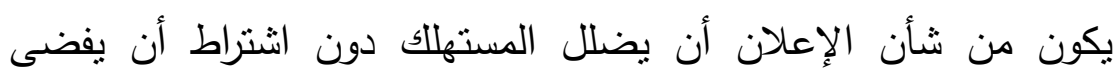

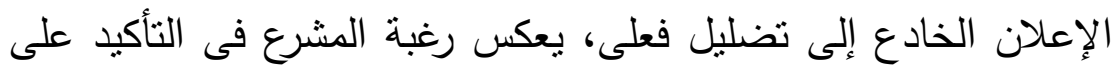

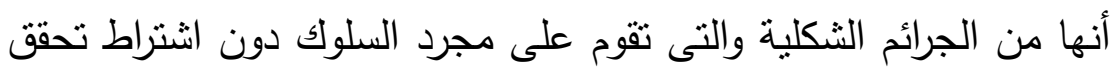
النتيجة.

11- لم يبين المنظم صراحة طبيعة الركن المعنوى اللازم لقيام الجريمة فى هذه الحالة، حيث سكت بنص المادة السادسة عن بيان ما إذا كانت هذه

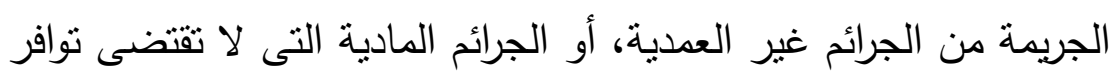
الركن المعنوى لقيامها. rا أن يتم تثديد العقوبات على الترويج للأدوية أو أخذ عمولات عن ذلك بأى طريق. 